Article

\title{
Antibiotic Resistance Genes and Potentially Pathogenic Bacteria in the Central Adriatic Sea: Are They Connected to Urban Wastewater Inputs?
}

\author{
Viviana Fonti ${ }^{1, *}$, Andrea Di Cesare ${ }^{2}{ }^{\oplus}$, Jadranka Šangulin ${ }^{3}{ }^{\oplus}$, Paola Del Negro ${ }^{1}$ and Mauro Celussi ${ }^{1}{ }^{1}$ \\ 1 National Institute of Oceanography and Applied Geophysics-OGS, 34151 Trieste, Italy; \\ pdelnegro@inogs.it (P.D.N.); mcelussi@inogs.it (M.C.) \\ 2 Water Research Institute, National Research Council (CNR-IRSA), Largo Tonolli 50, 28922 Verbania, Italy; \\ andrea.dicesare@cnr.it \\ 3 Institute of Public Health, 23000 Zadar, Croatia; jsangulin@zjz-zadar.hr \\ * Correspondence: vfonti@inogs.it; Tel.: +39-0402140721
}

Citation: Fonti, V.; Di Cesare, A.;

Šangulin, J.; Del Negro, P.; Celussi, M. Antibiotic Resistance Genes and Potentially Pathogenic Bacteria in the Central Adriatic Sea: Are They Connected to Urban Wastewater Inputs? Water 2021, 13, 3335. https://doi.org/10.3390/w13233335

Academic Editor: Xuetao Guo

Received: 18 October 2021

Accepted: 20 November 2021

Published: 24 November 2021

Publisher's Note: MDPI stays neutral with regard to jurisdictional claims in published maps and institutional affiliations.

Copyright: () 2021 by the authors Licensee MDPI, Basel, Switzerland. This article is an open access article distributed under the terms and conditions of the Creative Commons Attribution (CC BY) license (https:// creativecommons.org/licenses/by/ $4.0 /)$.

\begin{abstract}
Despite last decades' interventions within local and communitarian programs, the Mediterranean Sea still receives poorly treated urban wastewater (sewage). Wastewater treatment plants (WWTPs) performing primary sewage treatments have poor efficiency in removing microbial pollutants, including fecal indicator bacteria, pathogens, and mobile genetic elements conferring resistance to antimicrobials. Using a combination of molecular tools, we investigated four urban WWTPs (i.e., two performing only mechanical treatments and two performing a subsequent conventional secondary treatment by activated sludge) as continuous sources of microbial pollution for marine coastal waters. Sewage that underwent only primary treatments was characterized by a higher content of traditional and alternative fecal indicator bacteria, as well as potentially pathogenic bacteria (especially Acinetobacter, Coxiella, Prevotella, Streptococcus, Pseudomonas, Vibrio, Empedobacter, Paracoccus, and Leptotrichia), than those subjected to secondary treatment. However, seawater samples collected next to the discharging points of all the WWTPs investigated here revealed a marked fecal signature, despite significantly lower values in the presence of secondary treatment of the sewage. WWTPs in this study represented continuous sources of antibiotic resistance genes (ARGs) ermB, $q n r S$, sul2, tetA, and bla $a_{\mathrm{TEM}}$ (the latter only for three WWTPs out of four). Still, no clear effects of the two depuration strategies investigated here were detected. Some marine samples were identified as positive to the colistin-resistance gene $m c r-1$, an ARG that threatens colistin antibiotics' clinical utility in treating infections with multidrug-resistant bacteria. This study provides evidence that the use of sole primary treatments in urban wastewater management results in pronounced inputs of microbial pollution into marine coastal waters. At the same time, the use of conventional treatments does not fully eliminate ARGs in treated wastewater. The complementary use of molecular techniques could successfully improve the evaluation of the depuration efficiency and help develop novel solutions for the treatment of urban wastewater.
\end{abstract}

Keywords: $16 \mathrm{~S}$ rDNA; fecal bacteria; antibiotic resistance; marine water; sewage; potentially pathogenic bacteria

\section{Introduction}

Treated and untreated urban wastewaters (i.e., sewage) represent important point sources of microbial pollution for marine coastal areas [1-3]. Despite last decades' interventions within regional and communitarian programs, the majority of the objectives addressing the management of urban wastewater have not been achieved or partially achieved, with the Mediterranean Sea still receiving poorly treated sewage. Discharge of untreated or minimally processed wastewater is still a common practice in certain Mediterranean countries, while other regions face chronic malfunctioning of a few wastewater 
treatment plants (WWTPs) [4,5]. Basic mechanical treatments (i.e., "primary treatments") aim at removing solids, fats, and sand. Still, they do not substantially affect fecal pollution indicators (e.g., fecal coliforms and streptococci, fecal sterols, and potentially pathogenic bacteria-i.e., PPB) nor bacterial community structure [6]. Most WWTPs are designed to remove nutrients and biodegradable organic compounds and reduce the pathogen load through additional aerobic biological processes (i.e., "secondary treatment") and a final disinfection step. However, conventional treatments do not target most emergent contaminants, including antibiotic-resistant genes (ARGs), antibiotic-resistance bacteria, and opportunistic pathogens, with urban WWTPs becoming a major source of microbial pollution [7-10]. Marine coastal environments, as the WWTP effluent receiving bodies, have the potential of disseminating and promoting the establishment of ARGs and other microbial pollutants $[2,11,12]$, thus facilitating the emerging of new antimicrobial resistance (AMR) pathways [13-15] and the exposure of millions of people to disease and opportunistic pathogens [16-18]. Recent studies have shown that people's probability of contracting gastrointestinal and non-gastrointestinal illnesses increases in correlation with aquatic recreational activities because of antibiotic-resistant bacteria and other community-acquired microorganisms $[19,20]$. Furthermore, frequent bathing in coastal waters has been shown to be associated with gut colonization by E. coli harboring ARGs, including, for example, bla $a_{\mathrm{CTX}-\mathrm{M}}$ genes, which provide resistance to clinically relevant antibiotics (cefotaxime) and which are easily mobilized via horizontal gene transfer (HGT), thus increasingly found in natural environments as well as in WWTPs [21-23].

The microbiological quality of coastal water is routinely assessed by enumerating Fecal Indicator Bacteria (FIB) (i.e., Escherichia coli and enterococci) through culture-based methods $[24,25]$. However, FIB association with gastrointestinal and non-gastrointestinal diseases is currently questioned. Several bacteria occurring in natural environments and causing infectious disease are not primarily associated with human or animal fecal contamination [26-28]. At the same time, studies have shown that substantial populations of fecal bacteria can persist and regrow in aquatic environments, followed by the discovery of environmentally adapted populations of E. coli and by retrieving fecal bacteria in the absence of obvious fecal sources [29-31]. Moreover, most bacteria are or become unculturable because of specific metabolic requirements, physiological conditions, or the disinfection process [7].

It is also worth pointing out that routine monitoring of coastal waters is specifically addressed to the assessment of the quality of bathing waters, whereas the control of the environmental status in areas of treated wastewater discharge is spatially scattered and mainly dependent on local/regional policies. In this respect, information about the diffusion of ARGs and of non-conventional, potentially pathogenic bacteria in the Mediterranean is very scarce. To the best of our knowledge, no dedicated study on the presence of ARGs in Adriatic waters has been performed so far. Driven by this paucity of data, we aimed at depicting the transfer of these types of microbial pollution from WWTPs to seawater, following the hypothesis that the sewage treatment technology affects not only the spreading of classical FIB but also the abundance of other potential pathogens and ARGs. We, therefore, sampled both treated wastewater and seawater in the proximity of discharge points of four WWTPs characterized by different treatment technologies.

\section{Materials and Methods}

\subsection{Study Area and Sampling}

Four urban WWTPs with outfalls in the central Adriatic Sea were here investigated (Figure 1) in the framework of the Interreg Italy-Croatia project AdSWiM [32]. The Katalinića Brig and Stobreč WWTPs are part of the Split-Solin public sewage system (Croatia). Their submarine outfalls discharge in the Split Channel, at $1.30 \mathrm{~km}(43 \mathrm{~m} \mathrm{depth})$ and $2.75 \mathrm{~km}$ (37 m depth) from the shore, respectively, and are about $5 \mathrm{~km}$ away from each other [33]. Katalinića Brig WWTP receives both municipal and rainfall-runoff wastewater $\left(122,000 \mathrm{PE}\right.$ capacity, about $35,000 \mathrm{~m}^{3}$ / day average flow rate), and it is designed to remove solids by coarse and fine grids (i.e., primary treatment). Stobreč WWTP receives mostly 
municipal wastewater (138,000 PE capacity, about $33,000 \mathrm{~m}^{3} /$ day average flow rate). Like the Katalinića plant, it is designed for the mechanical treatment of sewage, but oil is also removed. Zadar WWTP receives mainly municipal wastewater with minor contributions of other types of wastewaters (i.e., rainfall-runoff and about $5 \%$ from septic tank wastewater). It is designed with 100,000 PE capacity, with an average flow rate of 22,600 $\mathrm{m}^{3} /$ day. The outfall pipe discharges at $2 \mathrm{~km}$ from the shoreline ( $34 \mathrm{~m}$ depth). In the Zadar plant, after removing coarse and fine solids, sand, and grease by mechanical treatment (i.e., by grids and gravitational deposition), wastewater is treated in activated sludge tanks for the aerobic biodegradation of organic pollutants and the removal of nutrients (i.e., secondary treatment). Before the unloading, the treated sewage is clarified by gravity deposition and transition in secondary precipitators. The Francavilla a Mare WWTP serves the municipality of Pescara (Italy) for the treatment of municipal wastewater (38,000 PE). The outfall pipe discharges at $2.5 \mathrm{~km}$ from the shoreline ( $15 \mathrm{~m}$ depth). As with the Zadar WWTP, Francavilla WWTP includes a biological treatment by activated sludge. However, the sewage inflow is divided into two streams, of which only one is treated in the activated sludge tanks due to plant under-sizing. The other stream undergoes a series of mechanical treatments, including surface aeration in a trickling filter, that decrease the biological oxygen demand $\left(\mathrm{BOD}_{5}\right)$. The two streams are then reunited for final disinfection by peracetic acid.

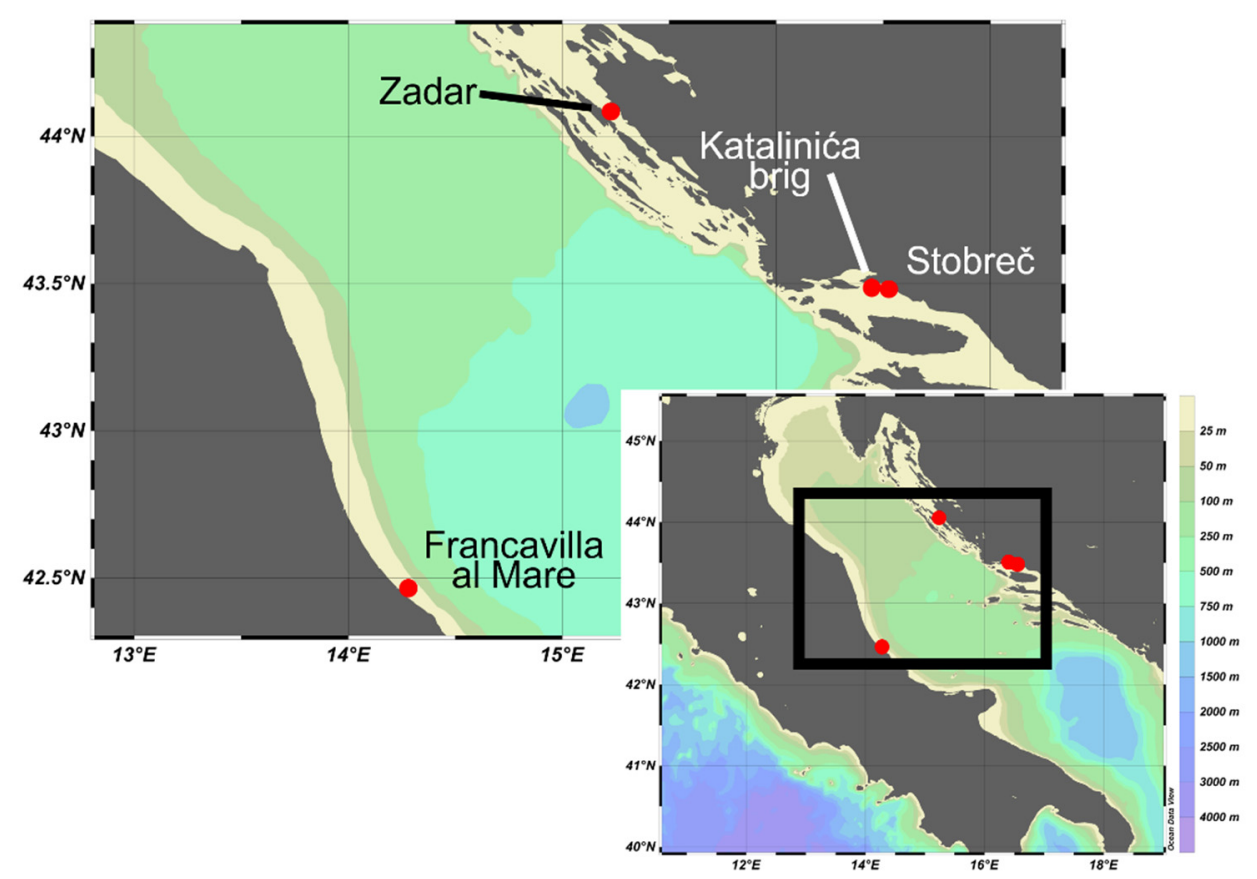

Figure 1. Locations of WWTPs outfalls at sea (Adriatic Sea).

The sampling activities were carried out (almost) monthly in spring and summer 2020 (from April to September). We collected extra samples in the Croatian sites in July 2019 and autumn 2019/winter 2020 (Table S1). Samples of treated sewage were taken before unloading, just upstream the injection into the discharging pipeline. Seawater samples were collected in the proximity of each WWTP outfall $1 \mathrm{~m}$ above the main diffusion point of the pipelines by means of $5 \mathrm{~L}$ Niskin bottles. While samples for FIB enumeration were taken with the same frequency for seawater and treated sewage, seawater samples dedicated to DNA extraction for the subsequent analyses of ARGs and microbial community structure were taken at selected time points.

\subsection{Microbiological Analyses}

Sample aliquots of $50 \mathrm{~mL}, 5 \mathrm{~mL}, 0.5 \mathrm{~mL}$, and $0.05 \mathrm{~mL}$ were filtered, in three replicates, through $0.45 \mu \mathrm{m}$ pore size sterile membrane filters $(47 \mathrm{~mm}$ diameter made in hydrophilic 
mixed cellulose esters, PALL Corporation) and incubated onto selective media for the enumeration of fecal indicator bacteria (FIB, i.e., E. coli and enterococci), in the following conditions: at $44{ }^{\circ} \mathrm{C}$ for $24 \mathrm{~h}$ onto TBX (Tryptone Bile X-glucuronide) agar plates, and at $37^{\circ} \mathrm{C}$ for $48 \mathrm{~h}$ onto on Slanetz-Bartley agar plates, for $E$. coli and enterococci, respectively. Colonies that displayed the characteristic positive colors (i.e., blue-green for TBX-agar medium and reddish-brown for Slanetz-Bartley agar medium) were counted. The result was expressed as the number of colonies forming units (CFU) in $100 \mathrm{~mL}$ of sample. In this study, Pseudomonas aeruginosa was selected as a model of emerging pathogens of non-fecal origins and environmental relevance [34-36]. Its enumeration was performed by incubating membranes onto Cetrimide-agar plates at $44{ }^{\circ} \mathrm{C}$ for $48 \mathrm{~h}$, following the procedure used for fecal indicator bacteria. Analyses were performed in two replicates.

\subsection{DNA Extraction}

Seawater and sewage samples were filtered onto $0.22 \mu \mathrm{m}$ hydrophilic PES membrane filters (PALL Laboratory) and stored at $-80^{\circ} \mathrm{C}$ until processing. Filtration was endured until clogging of membrane pores. Filtered volumes were in the range of $1-2 \mathrm{~L}$ for seawater samples and $40-500 \mathrm{~mL}$ for sewage samples, respectively.

Genomic DNA was isolated from filters using the DNeasy PowerWater Kit (Qiagen) following the manufacturer's protocol, with few modifications aimed at increasing the extraction yield [37]. Filters were cut in half and were extracted separately and pooled together after completion of the extraction procedure. After adding the lysing buffer provided by the manufacturer, samples underwent three cycles of incubation at $70^{\circ} \mathrm{C}$ for $5 \mathrm{~min}$ followed by $2 \mathrm{~min}$ vortexing at the maximum speed. We then proceeded as described in the kit handbook. The DNA concentration was measured using a Qubit Fluorometer (ThermoFisher). DNA extracts were dispensed into aliquots and stored at $-80{ }^{\circ} \mathrm{C}$ until further processing.

\subsection{Microbial Community Characterization by High-Throughput Amplicon Sequencing}

The V4-V5 hypervariable region of the 16S rRNA gene was amplified using universal primer pair 515F-Y/926R, which allows differentiating taxa unresolvable with the 515F/806R primer pair for the V4 region (Parada et al., 2016). Libraries were prepared following the Illumina protocol [38] and then pooled in equal molar ratios for pair-end sequencing (250 bp) on an Illumina MiSeq System (Illumina, San Diego, CA, USA) at the ARGO Open Lab Platform (Area Science Park, Trieste, Italy). Samples were sequenced in two runs. Since the library size of the second run was up to $10 \times$ higher than the first one, we subsampled the second run reads prior to any bioinformatics analysis (i.e., we filtered reads with the sum of extended errors $\leq 1$ out and then evened the library sizes to 250,000 using "ShortRead" package for random sampling [39]). Sequences were deposited in the NCBI Sequence Read Archive (SRA) with bioproject numbers PRJNA771212 and PRJNA771227. Reads processing was performed using the "DADA2" package (v 1.20.0) in R 4.1.0 [40,41], following the package instructions. After primer removal and visual inspection of the read quality profiles, forward and reverse reads were truncated at positions 220 and 190, respectively. Before running the dada algorithm (pseudo-pooling method), we enforced monocity of the estimated error rates (to better cope with binned scored quality and, thus, preventing false positives) by manual correction. Chimeric sequences were identified and removed in consensus mode (chimeras were calculated to make up about $6.3 \%$ of the merged amplicon sequence variants-i.e., ASVs). Non-target-length sequences and any singletons that arose after reads merging and chimera removal were filtered out. Taxonomy was assigned using the native implementation of the naive Bayesian classifier method [42] provided by the DADA2 package and using SILVA SSU reference database version $138[43,44]$. The subsequent downstream analyses (i.e., inspection, visualization, and pre-processing) were performed using "phyloseq", "ggplot2", and "ranacapa" packages [45-47]. The whole prokaryotic diversity was captured by the sequencing effort, as shown by the rarefaction curves in Supplementary Materials (Figure S1). ASVs with 
unassigned domains and those taxonomically assigned as chloroplast, mitochondria, and Eukaryota were removed. Phyla with both extremely low prevalence and read count were filtered out in preliminary inspection phases. Subsequently, processed sequences were imported into QIIME2 [48], aligned using MAFFT [49], and then used to infer an unrooted phylogenetic tree based on the FastTree [50].

\subsection{Quantification of Antibiotic Resistance Genes (ARGs)}

DNA extracts were diluted in nuclease-free water (i.e., $10 \times$ in the case of seawater samples, $10-100 \times$ for treated sewage samples, based on total DNA quantification) and analyzed for the quantification of $16 \mathrm{~S}$ rRNA gene (as housekeeping gene) and 8 ARGs genes conferring resistance to commonly used antibiotic families, such as tetracyclines (tetA), sulfonamides (sul2), macrolides (ermB), fluoroquinolones ( $q n r S)$, beta-lactams (bla $a_{\mathrm{TEM}}$, $b l a_{\mathrm{CTX}-\mathrm{M}}$, and $\left.b l a_{\mathrm{OXA}}\right)$, and colistin resistance gene $(m c r-1)$. qPCR assays were performed in SYBR green chemistry (SsoAdvanced universal SYBR Green supermix, Bio-Rad), using the CFX96 Touch Real-Time PCR Detection System (Bio-Rad) in the analytic conditions previously described [51]. Before quantification, a potential PCR inhibition effect was tested by dilution method (i.e., $10 \times, 100 \times, 1000 \times$ ), as described by Di Cesare et al. [52]. Synthetic consensus sequences from the Comprehensive Antibiotic Resistance Database (CARD; [53]) cloned into the pEX-A128 plasmid vector (Eurofins) were used as positive controls. Standard calibrations curves were built using the purified, quantified, and diluted amplicons of each positive control, thus with linearized PCR products to avoid issues due to supercoiled circular configuration [54]. Details about the primer pairs used in this study are shown in the Supplementary Materials (Table S2) with the respective annealing $\mathrm{T}$ [51,52,55-61]. Quantification was performed in two technical replicates. The specificity of the qPCR assay was investigated by melting curve test. The limit of quantification (LOQ) of the standard curves, as defined by [62], and the other parameters for gene quantification are shown in Supplementary Materials (Table S3). For the samples in which the threshold cycle was below the LOQ but above the limit of the GPCR (theoretically three copies per PCR; Bustin et al., 2009), the analyzed gene was considered present but not quantifiable [63]. ARG abundances were expressed as ARG copies per copy of $16 \mathrm{~S}$ rRNA gene to prevent differences among sample cell abundances from becoming a confounding factor.

\subsection{Statistical Analyses}

Statistical analyses were carried out in $\mathrm{R} 4.1 .0$ [41]. The correlation between the two FIB (i.e., E. coli and enterococci) and between FIB and P. aeruginosa has been tested in both types of samples by Spearman rank correlation analysis due to the unbalanced design, heteroscedasticity of data, and presence of potential outliers, as assessed by data exploration [64].

As regards the $16 \mathrm{~S}$ sequencing data, we applied a preliminary filtration to remove rare ASVs (total sum $>1 \times 10^{-4} \%$ ) prior to performing any statistical analysis or ordination. The resulting dataset comprised 8,693,932 reads from the 45 analyzed samples, for a total of 14,454 prokaryotic ASVs. Data were not rarefied as the number of reads in samples did not vary by much, while rarefaction could result in information loss and a high rate of false positives [65]. A natural $\log (1+x)$ transformation was applied prior to data ordination of either overall microbiomes or data subsets, using Bray-Curtis distance to calculate the dissimilarity matrices. Taxa that most contributed to beta-diversity were identified by pairwise comparisons (Bray-Curtis distances) of categorical variables of interest by SIMPER analysis, followed by Kruskal-Wallis one-way ANOVA on ranks to test for significance with $p$-values correction by false discovery rate [66].

As the microbial signature of fecal pollution, a data subset of fecal indicator taxa was obtained extracting ASVs belonging to the traditional fecal indicator taxa (i.e., the family Enterobacteriaceae, which includes the genus Escherichia, and the family Enterobacteriaceae, that includes the genus Enterococcus), and to alternative fecal indicator taxa, according to the approach proposed by Newton et al. [67]. In particular, five feces-associated bac- 
terial families (i.e., Bacteroidaceae, Porphyromonadaceae, Clostridiaceae, Lachnospiraceae, and Ruminococcaceae) were used as signatures of fecal (both human and non-human) contamination. Three sewer infrastructure-associated bacterial genera (i.e., Acinetobacter, Arcobacter, and Trichococcus) were used as signatures of sewage contamination [31]. The diversity and abundance of potentially pathogenic bacteria were investigated by creating a data subset of 60 genera, as selected from a combination of public databases ([68]; https: / / www.bode-science-center.com/center/relevant-pathogens-from-a-z.html (accessed on 15 September 2021)). For this study, we included Shewanella, as strains affiliated with this genus are considered emerging marine pathogens [28,69].

Differences between sampling areas and between types of treatment (i.e., with or without secondary treatment) for the composition of fecal bacterial communities or in the distribution of PPB were assessed by ANOSIM (analysis of similarity) based on a BrayCurtis dissimilarity matrix. Due to the high sparsity of PPB in the seawater sample dataset, we performed a differential abundance analysis of those genera using a generalized linear model based on the negative binomial distribution, with $p$-values corrected by BenjaminiHochberg corrected $p$-values using the R package DESeq2 [70].

Statistical differences among groups were examined by multiple comparisons with the Kruskal-Wallis test, followed by a post hoc test using the criterium Fisher's least significant difference, as in the R packages agricolae v1.3.5.

\section{Results}

\subsection{Enumeration of FIB and P. aeruginosa as Assessed by Microbiological Analyses}

FIB in the treated sewage of the two Split WWTPs (i.e., Katalinića and Stobreč, i.e., primary treatment only) were from $10^{2}$ to $10^{3}$-fold higher than in the Zadar WWTP, and $10^{5}$ to $10^{8}$-fold higher than in the Francavilla's one (Figure 2). Treated sewage E. coli average count was $4.7 \times 10^{8}, 3.8 \times 10^{8}, 3.2 \times 10^{5}$, and $3.9 \times 10^{0} \mathrm{CFU} / 100 \mathrm{~mL}$ for Katalinića, Stobreč, Zadar, and Francavilla, respectively, while enterococci average count was $8.6 \times 10^{5}, 5.4 \times 10^{6}$, $4.8 \times 10^{4}$, and $5.0 \times 10^{0} \mathrm{CFU} / 100 \mathrm{~mL}$, respectively. FIB in the treated sewage from the two Split WWTPs never went below $1.0 \times 10^{7} \mathrm{CFU} / 100 \mathrm{~mL}$ and $2.0 \times 10^{5} \mathrm{CFU} / 100 \mathrm{~mL}$ for E. coli and enterococci, respectively. Moreover, their treated sewage was characterized by occasional peaks of FIB, with $E$. coli values ranging from $0.7-2.0 \times 10^{9} \mathrm{CFU} / 100 \mathrm{~mL}$ for both Katalinića and Stobreč (July 2019 and February 2020). FIB in the treated sewage from Francavilla WWTPs was characterized by the lowest counts of FIB (and P. aeruginosa), often with undetectable values.

P. aeruginosa counts in the two Split WWTPs showed a peak in April $2020\left(1.1 \times 10^{8}\right.$ and $0.9 \times 10^{8} \mathrm{CFU} / 100 \mathrm{~mL}$ ), with average values of 2.2 and $2.5 \times 10^{7} \mathrm{CFU} / 100 \mathrm{~mL}$ and min values of $1.8 \times 10^{5}$ and $9.0 \times 10^{4} \mathrm{CFU} / 100 \mathrm{~mL}$, for Katalinića and Stobreč plants, respectively. Like FIB, P. aeruginosa in the treated sewage from Zadar WWTP was $10^{2}$-fold lower than the two Split WWTPs. At the same time, it was often undetected in the treated sewage from Francavilla WWTP (max value: $1.1 \times 10^{1} \mathrm{CFU} / 100 \mathrm{~mL}$ ).

Seawater samples collected in the proximity of the sewage outfall points were characterized by the FIB average contents of FIB: E. coli $2.7 \times 10^{2}, 8.5 \times 10^{2}, 9.2 \times 10^{0}$, and $0.5 \times 10^{0} \mathrm{CFU} / 100 \mathrm{~mL}$ and enterococci $1.8 \times 10^{2}, 7.8 \times 10^{2}, 5.1 \times 10^{0}$, and $1.2 \times 10^{2} \mathrm{CFU} / 100 \mathrm{~mL}$, for Katalinića, Stobreč, Zadar, and Francavilla, respectively. Conversely, $P$. aeruginosa count in seawater was higher than FIB, with $1.7 \times 10^{4}, 1.2 \times 10^{4}$, $5.5 \times 10^{4}$, and $5.5 \times 100 \mathrm{CFU} / 100 \mathrm{~mL}$, for Katalinića, Stobreč, Zadar, and Francavilla, respectively.

A positive correlation was found between the abundance of $E$. coli and enterococci both in treated sewage samples $(S=580, \rho=0.857, p<0.001)$ and in seawater $(S=258, \rho=0.936$, $p<0.001)$. In contrast, there was no significant correlation between the abundance of FIB and Pseudomonas in both seawater and treated sewage. 


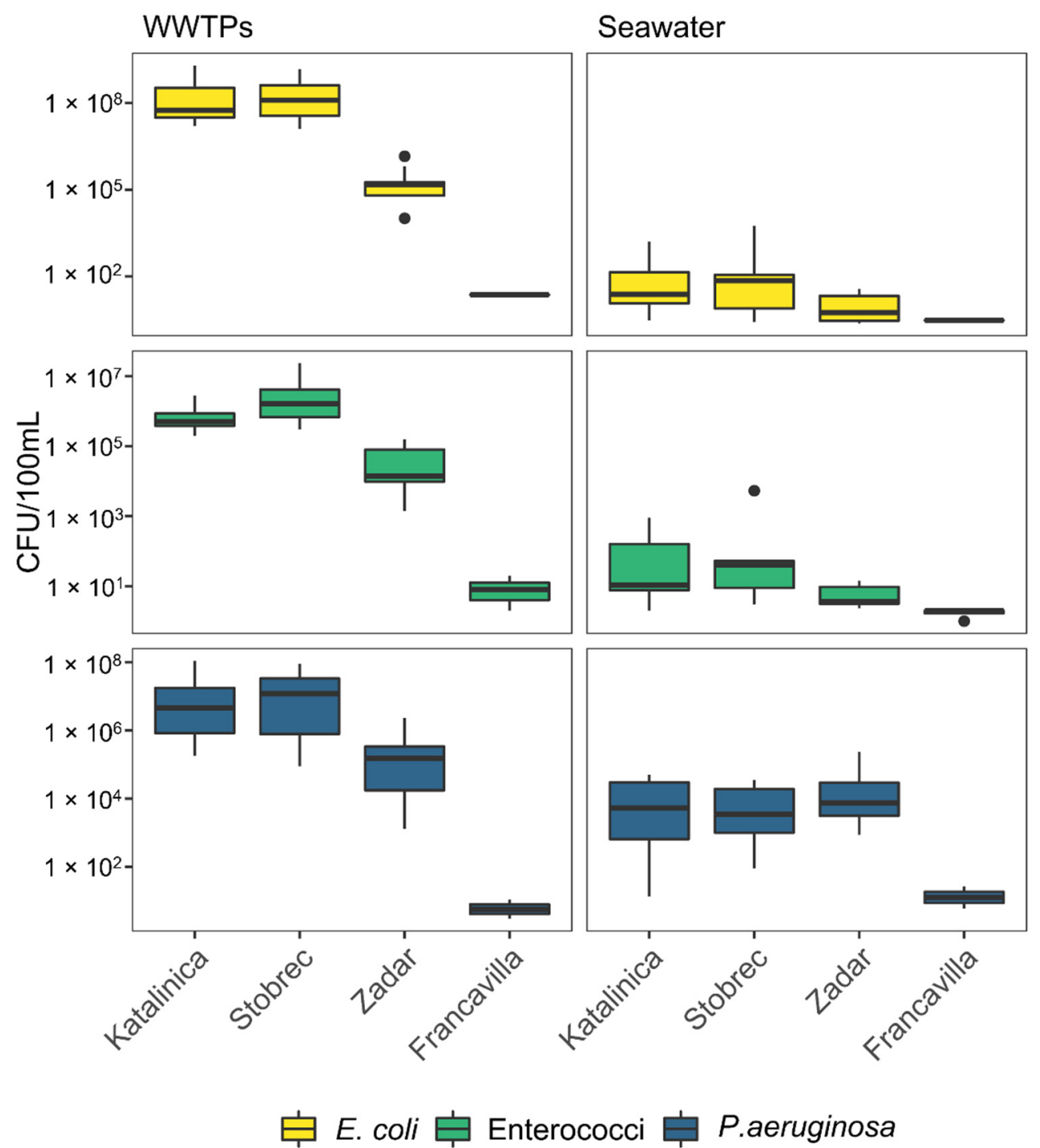

Figure 2. Box plots depicting the variation in microbiological counts (by membrane filtration method followed by plate cultivation) in treated sewage (WWTPs) and seawater samples. The median values $(-)$, the first $(\square)$, the third $(\square)$, the minimum and maximum values (whiskers) and the outliers (•) are shown.

\subsection{Bacterial Community Structure}

Bacterial community structure in treated sewage was mainly dominated by Proteobacteria (29.0-75.9\%), Firmicutes (1.4-49.2\%), Bacteroidota (2.9-40.4\%), and Actinobacteriota $(1.2-20.8 \%)$, as shown in Figure S2. Ordination based on Bray-Curtis distances (i.e., PCoA, Figure S3) showed that treated sewage samples obtained from Katalinića and Stobreč WWTPs (i.e., primary treatment only) were very similar in bacterial community structure and different from those obtained by Francavilla and Zadar WWTPs, which formed two separated clusters. In the presence of secondary treatment (i.e., Francavilla and Zadar WWTPs) Firmicutes decreased significantly (SIMPER, fdr corrected $p$-value $<0.001$ ) by $24.7 \%$ on average, in favor of Actinobacteriota, Chloroflexi, Patescibacteria and Planctomycetota (SIMPER, fdr corrected $p$-value $<0.01$ for Actinobacteriota, $p$-value $<0.001$ for the others). Francavilla WWTP effluent had an average percent contribution of Actinobacteriota lower than the Zadar WWTP one by $10.1 \%$ (SIMPER, fdr corrected $p$-value $<0.01$ ). Deinococcata, Acidobacteriota, and Myxococcota contribute to minor $(<5 \%)$, yet significant, differences between the two WWTPs. 
Abundances of ASVs affiliated with traditional and alternative fecal indicator bacteria in treated sewage are shown in Figure 3. Traditional fecal indicator bacteria in treated sewage from WWTPs with primary treatment only (i.e., Katalinića and Stobreč) accounted for relative abundances of $0.6-3.6 \%$, while in the presence of a secondary treatment (i.e., Francavilla and Zadar), they were statistically lower (ANOSIM, R $=0.5852, p$-value $<0.001$ ) and ranged between $0.03-1.6 \%$. In both cases, Enterobacteriaceae exceeded Enterococcaceae by about an order of magnitude. Alternative feces-associated families (i.e., Bacteroidaceae, Porphyromonadaceae, Clostridiaceae, Lachnospiraceae, and Ruminococcaceae) covered a very high proportion of the total diversity (up to $34.5 \%$, in Katalinića, treated sewage), although Clostridiaceae and Porphyromonadaceae were detected in low abundances $(<0.5 \%)$. Like the traditional fecal indicator families Enterobacteriaceae and Enterococcaceae, the relative abundances of alternative feces-associated families were statistically higher in treated sewage from WWTPs with primary treatment only (ANOSIM, R $=0.4685, p$-value $<0.001$ ). Sewage-associated genera (i.e., Acinetobacter, Arcobacter, and Trichococcus) were main components of treated sewage as well (i.e., up to $21.7 \%$ in Katalinića treated sewage), with higher relative abundances in the absence of a secondary treatment (ANOSIM, R $=0.4839$, $p$-value $<0.001$ ) but significant differences between Francavilla and Zadar treated sewage (ANOSIM, $\mathrm{R}=0.2058, p$-value $<0.05$ ).

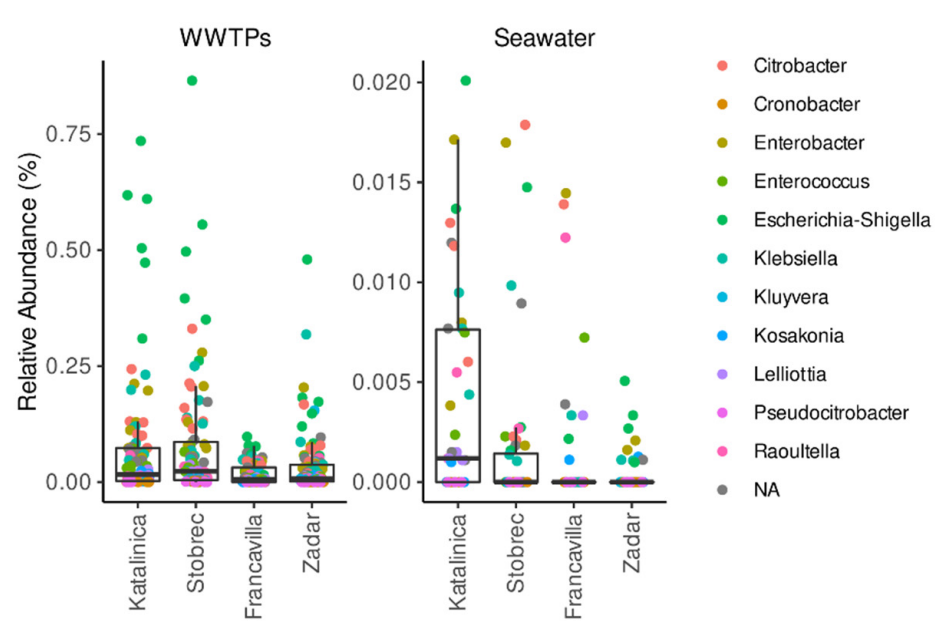

(a)

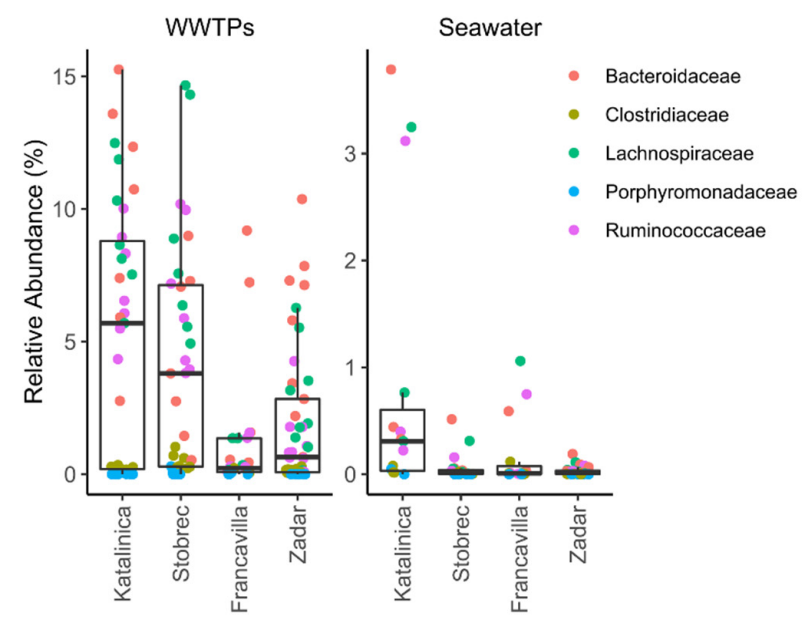

(b)

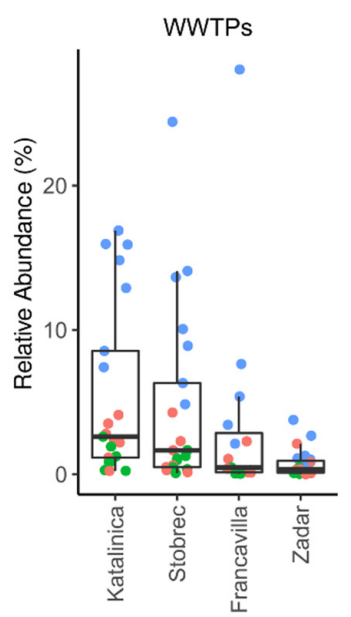

(c)

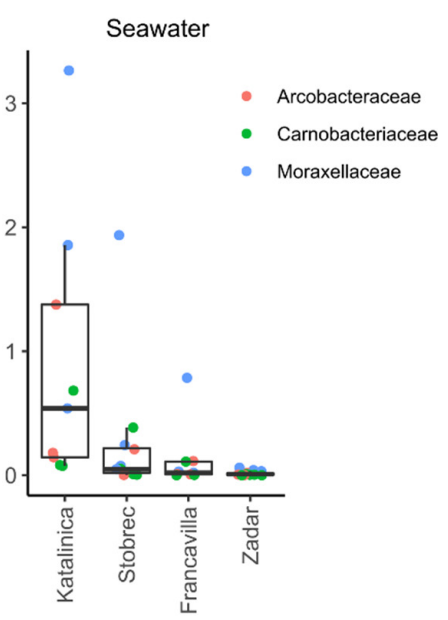

Figure 3. Relative abundances of fecal indicator bacteria in treated sewage (WWTPs) and seawater samples. (a) Traditional fecal indicator bacteria (i.e., families Enterobacteriaceae and Enterococcaceae). (b) Alternative fecal indicator taxa: fecesassociated families. (c) Alternative fecal indicator taxa: sewage-associated genera. Data are the average relative abundance of each taxon over time. Boxplots show the variation of the total relative abundances in each category. 


\subsection{Effect of WWTPs on Marine Community Structure}

Seawater samples collected next to WWTP outfalls showed a mild differentiation based on sampling site or type of treatment performed in the corresponding WWTP (Figure S3). The bacterial community structure was mainly dominated by Proteobacteria (45.1-50.2\%), Bacteroidota (16.6-21.6\%), Cyanobacteria (9.2-22.6\%), and in a lower contribution by Actinobacteriota (2.0-4.1\%) and Planctomycetota (1.3-4.5\%). Firmicutes accounted for relative abundances less than $1 \%$, except for samples collected next to the outfall pipe of Katalinića WWTP (i.e., average relative abundance $4.9 \%$ ) and for two other seawater samples (Figure S2). None of the phyla that contributed the most to the within-group similarities (i.e., $>70 \%$ as assessed by SIMPER) varied in a statistically significant fashion.

Abundances of ASVs affiliated with traditional and alternative fecal indicator bacteria in seawater samples collected next to the discharging points of WWTPs are shown in Figure 3. Traditional fecal indicator bacteria accounted for relative abundances up to $0.1 \%$ (i.e., the sum of taxa per sample), with differences between the type of sewage treatment performed by the WWTP discharging in the area and with Katalinića seawater samples with the highest relative abundances over time (ANOSIM, $\mathrm{R}=0.278, p$-value $<0.05$ ). However, we did not find any read affiliated with traditional fecal indicator bacteria in a few seawater samples. Enterococcaceae were significantly lower than Enterobacteriaceae (as observed for WWTP samples) and absent in the majority of the seawater samples. On the contrary, alternative fecal indicator taxa (both feces- and sewage-associated) were found in all seawater samples collected in this study. As observed for the treated sewage, Bacteroidaceae, Lachnospiraceae, and Ruminococcaceae were the main feces-associated families contributing to fecal pollution (Figure $3 \mathrm{~B}$ ). The distribution of feces- and sewage-associated taxa was not affected by the type of sewage treatment performed by the WWTP in each area, but it was site-specific (ANOSIM, $R=0.265, p$-value $<0.05$ ), with the Katalinića seawater samples with the highest contribution of both feces and sewage-associated families (i.e., average overtime was $4.3 \%$ and $2.7 \%$, for feces- and sewage-associated taxa, respectively).

We screened the treated sewage samples for a list of 60 genera of PPB (679 ASVs), and then we looked at their presence and distribution in seawater samples. Out of the 42 PPB genera found in the dataset (Figure 4), Alcaligenes, Propionibacterium, Ralstonia, Leptospira, and Serratia were not found in the marine samples. Acinetobacter, Coxiella, Prevotella, Streptococcus, Pseudomonas, Vibrio, Empedobacter, Paracoccus, and Leptotrichia were among the most abundant. Conversely, FIB Escherichia-Shigella and Enterococcus ranged between $0.002-0.03 \%$ and $0-0.003 \%$, respectively. The overall distribution of investigated PPB genera differentiated seawater samples based on the type of treatment performed in WWTPs discharging next to seawater sampling points (ANOSIM 0.2216 , $p$-value $<0.05$ ), with Katalinića seawater samples characterized by the highest relative abundances for several genera of PPB. However, despite differences in PPB distribution between samples, one-way ANOVA (on ranks, Kruskal-Wallis test, fdr correction applied) did not highlight any statistical difference associated with a specific site or type of treatment (performed in the WWTP discharging next to seawater sampling points). On the contrary, a differential abundance analysis based on the negative binomial distribution suggested that Acinetobacter was strongly associated with the seawater affected by the discharge from WWTP performing only primary treatment of sewage (Benjamini-Hochberg corrected $p$-values $<0.001$ ), while Sphingomonas, Legionella, Vibrio, Brevundimonas, and Pseudomonas were associated with the presence of a secondary treatment (Benjamini-Hochberg corrected $p$-values $<0.001)$. 

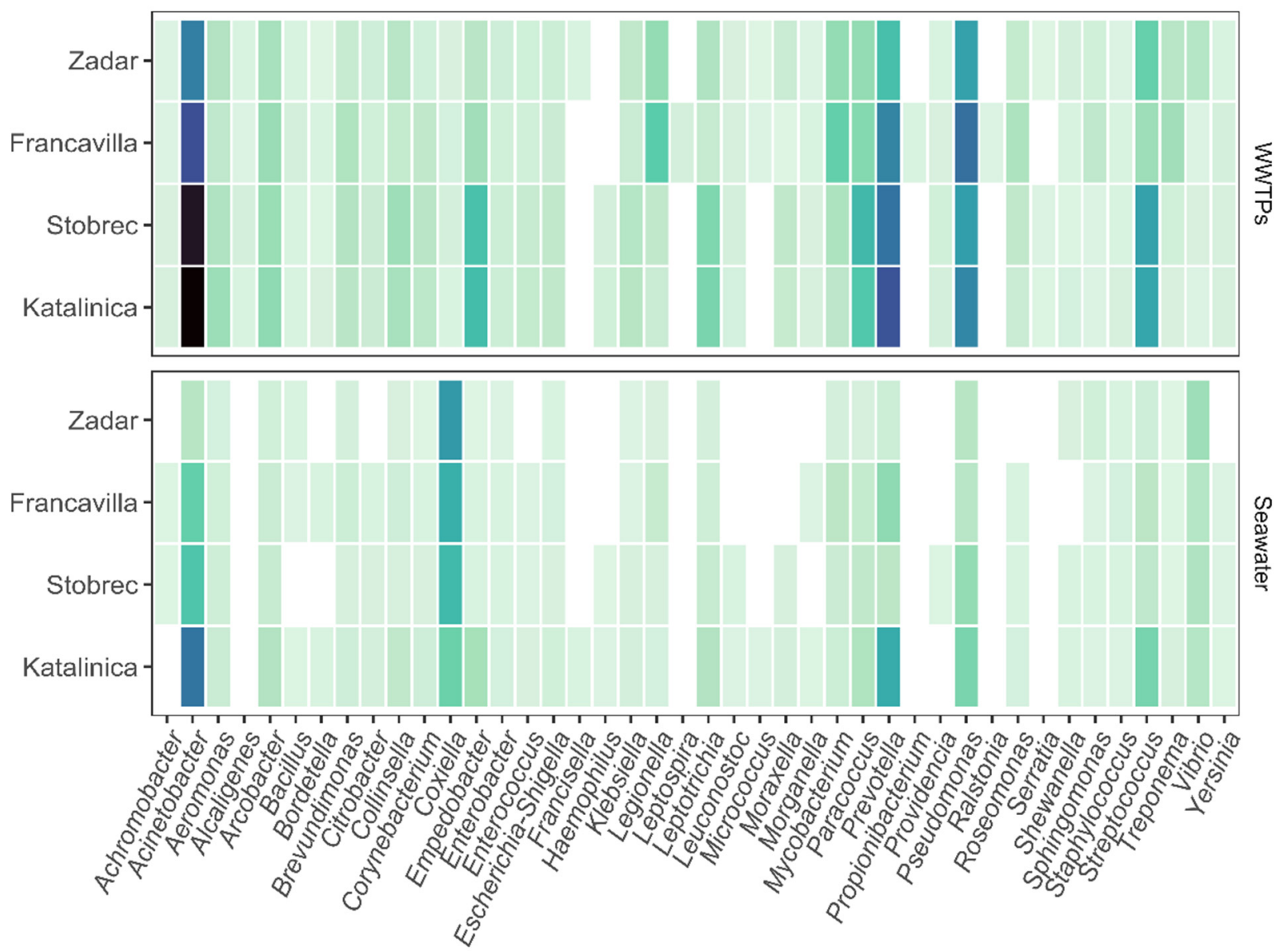

Figure 4. Potentially pathogenic bacteria in treated sewage (WWTPs) and seawater samples. Out of the 60 genera investigated Bacteriodes, Borrelia, Brucella, Burkolderia, Campylobacter, Chlamydia, Enterobacter, Laclercia. Listeria, Orientia, Rosemonas, and Salmonella were not found in the dataset. ASV raw counts are $\log (1+\mathrm{x})$ transformed to improve visualization and comparisons between samples. Tiles represent the average count over time per site. Higher values correspond to darker colors. White tiles indicate 0 reads.

The large majority of ASVs belonging to the PPB genera found in the seawater samples were also found in treated sewage (including Pseudomonas, which had only two ASVs found in seawater samples only). However, most ASVs belonging to Coxiella were found only in the seawater samples (96 out of 104). Similarly, several ASVs out of the 21 affiliated with Vibrio were exclusive for marine samples.

\subsection{ARGs in Treated Sewage and Receiving Marine Water}

erm $\mathrm{B}$, qnrS, sul2, and tet $\mathrm{A}$ were found in the highest concentrations in all WWTPs effluents here investigated, with tetA lower than the other three genes by one order of magnitude or more (Figure 5). Katalinića and Stobreč WWTPs were characterized by the presence of those four genes in all the surveyed months, unlike Francavilla and Zadar ones. erm B was found in concentrations statistically higher in Katalinića and Stobreč effluents than Francavilla and Zadar ones $(\mathrm{H}=32.50548$, $p$-value $<0.001)$. qnrS did not vary in a statistically significant manner among all tested treated sewage $(H=5.160097$, $p$-value $=0.16$ ). On the contrary, sul2 was significantly higher in Zadar and Francavilla effluents $(\mathrm{H}=7.509246, p$-value $<0.05)$, while there were no differences in the content of tet A among treated sewage from Zadar, Francavilla and Katalinića WWTPs $(\mathrm{H}=7.509246$, $p$-value $=0.0573)$, but tetA was significantly lower in Stobreč effluent $(\mathrm{H}=6.706772$, $p$-value $<0.01)$. 


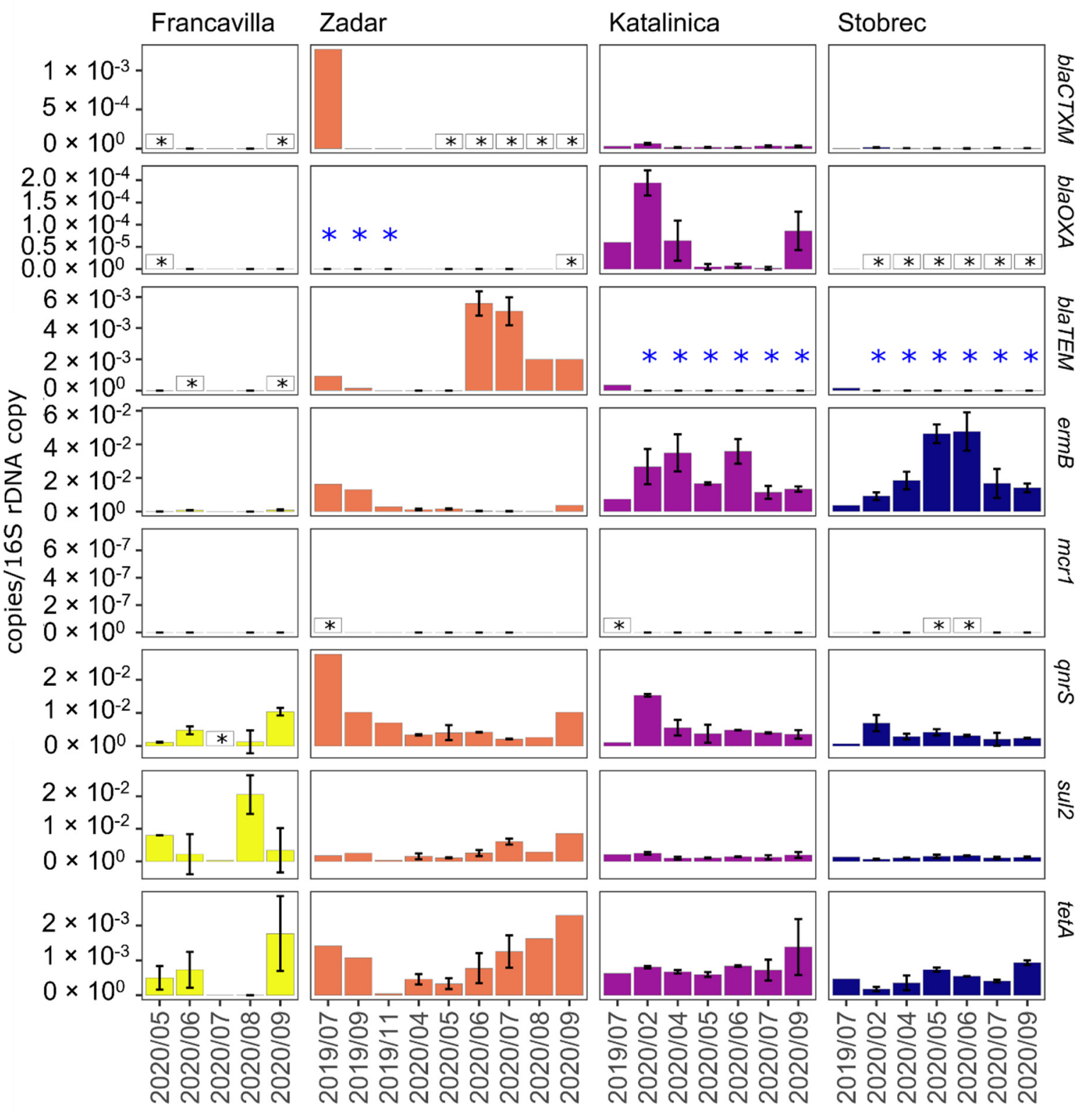

Figure 5. Content of ARGs in treated sewage samples over time. Black stars in white boxes are $<$ LOQ values. Blue stars indicate not quantifiable samples due to primer-specificity issues. Error bars show the standard deviation between biological replicates $(n=2)$.

Genes conferring resistance to beta-lactams, $b l a_{\mathrm{CTX}-\mathrm{M}}, b l a_{\mathrm{TEM}}$, and $b l a_{\mathrm{OXA}}$, were found in concentrations from 10 to 100 times lower than the other ARGs. bla treated sewage from Francavilla and Zadar WWTPs were negative or $\angle L O Q$, with the sole exception of 1 positive sample (each) in the Zadar WWTP. bla $a_{\text {OXA }}$ was found in quantifiable concentrations only in the Katalinića treated sewage, while in the Stobreč one, it was always positive but $<\mathrm{LOQ}$. bla $a_{\mathrm{TEM}}$ also was basically absent in Francavilla treated sewage, while it was detected in all the samples from the other three WWTPs, despite being not quantifiable for Katalinića and Stobreč ones due to primer-specificity issues. The colistin-resistance gene, $m c r-1$, was only found in four samples of treated sewage, all $<\mathrm{LOQ}$, but never found in samples collected at Francavilla WWTP.

Figure 6 shows ARG presence/absence distribution (\% of samples positive for a given gene) in marine sites investigated here due to the low number of observations as quantifiable abundances (i.e., we found several samples to be $<\mathrm{LOQ}$ or positive but not quantifiable due to specificity issues, as shown in Figure S4). As observed for WWTP 
samples, ermB, qnrS, sul2, and tet A were found in higher concentrations and more constantly than the other ARGs. On the contrary, the most abundant gene in marine samples was sul2, with concentrations up to $1.6 \times 10^{-3}$ copies / $16 \mathrm{~S}$ rDNA copy (Stobreč, February 2020). Interestingly, $m c r-1$ was rarely found and in concentration usually $<\mathrm{LOQ}$, although few seawater samples collected next to Francavilla and Zadar WWTP discharging points were higher than LOQ, with average values of $1.9 \times 10^{-4}$ and $1.4 \times 10^{-4}$ copies $/ 16 S \mathrm{rDNA}$ copy, respectively.

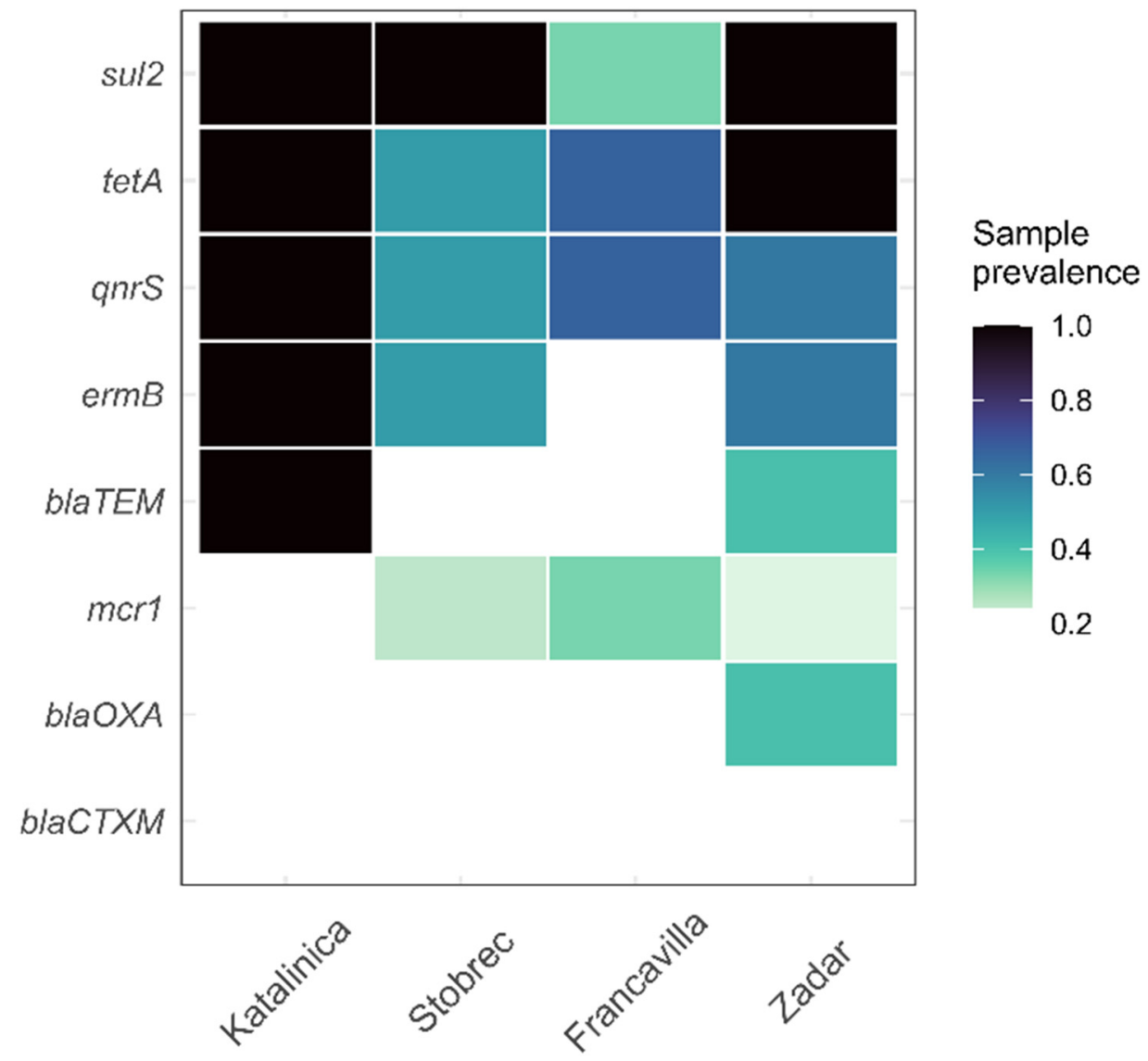

Figure 6. Sample prevalence ratio (\% of samples positive for a given gene) of ARGs in seawater samples. As the content of the ARGs investigated in this study was often not quantifiable, observations were converted as presence/absence data and then plotted as prevalence ratio.

Seawater samples collected next to Francavilla WWTP discharging point were often negative or $<\mathrm{LOQ}$ for most ARGs, except for $q n r S$ and $m c r-1$ that had an average content of $1.4 \times 10^{-4}$ and $1.9 \times 10^{-4}$ copies/16S rDNA copy, respectively. Seawater samples collected next to Katalinića and Stobreč WWTP discharging points were characterized by the highest concentrations of ARGs, with sul2 average content of $2.4 \times 10^{-4}$ and $4.5 \times 10^{-4}$ copies/16S rDNA copy, respectively, qnrS average content of $1.5 \times 10^{-4}$ and $1.2 \times 10^{-4}$ copies/16S rDNA copy, respectively, and with ermB positive but not quantifiable in Katalinića seawater samples and having an average content of $6.7 \times 10^{-4}$ copies $/ 16 S$ rDNA copy in Stobreč ones. tet A was undetectable or $<\mathrm{LOQ}$ in Stobreč seawater samples, while it was found in an average content of $7.8 \times 10^{-5}$ copies $/ 16 S$ rDNA copy in Katalinića once. While seawater samples collected next to Zadar discharging point were often positive for the majority of the ARGs (Figure 6), concentrations were frequently <LOQ. In particular, tet $\mathrm{A}$ and $q n r S$ were always undetectable or $<\mathrm{LOQ}$, while ermB and $s u l 2$ were quite variable, with max values of $3.2 \times 10^{-4}$ and $2.0 \times 10^{-5}$ copies/16S rDNA copy, respectively.

bla $a_{\text {TEM }}$ was relevant only in samples collected next to Katalinića discharging point, with all samples positive despite not being quantifiable due to specificity issues (tested 
by melting curve) except for one $<\mathrm{LOQ}$. bla $a_{\mathrm{OXA}}$ and $b l a_{\mathrm{TEM}}$ were found only in two out of the five seawater samples collected next to Zadar WWTP and with concentrations $<$ LOQ. bla $a_{\mathrm{CTX}-\mathrm{M}}$ gene was negative in all areas investigated.

\section{Discussion}

In this study, we sampled treated sewage from four WWTPs (two performing only basic mechanical treatments and the other two performing bio-oxidation in activated sludge tanks) over at least six months, and we investigated their role as a source of microbial pollution in marine coastal areas. Treated sewage that underwent a primary treatment exclusively was characterized by a higher content of culturable FIB (including the opportunistic pathogen Pseudomonas aeruginosa) than treated sewage that underwent an additional secondary treatment, as well as by microbial communities with higher relative abundances of fecal indicator taxa (both feces- and sewage-associated). As expected, in the presence of a final disinfection step (i.e., with peracetic acid, Francavilla WWTP), the number of culturable E. coli, enterococci, and P. aeruginosa decreased further and significantly, often up to $0 \mathrm{CFU} / 100 \mathrm{~mL}$ values. However, a comparison between plate numbers and relative abundances obtained by NGS showed that several reads affiliated with genera Escherichia-Shigella, Enterococcus, and Pseudomonas could still be found in the treated sewage from Francavilla WWTP and may also account for numbers similar to the ones obtained for the other WWTP with secondary treatment (i.e., Zadar WWTP; Figure 7).

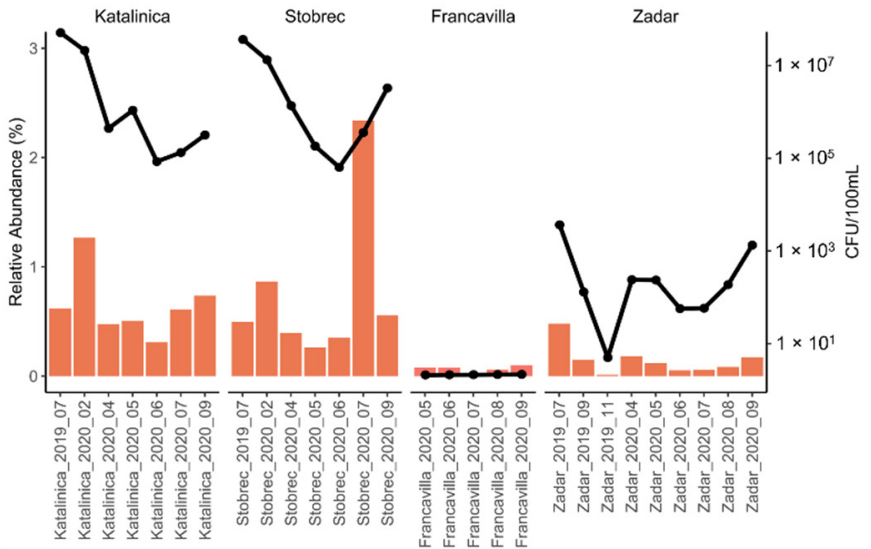

(a)

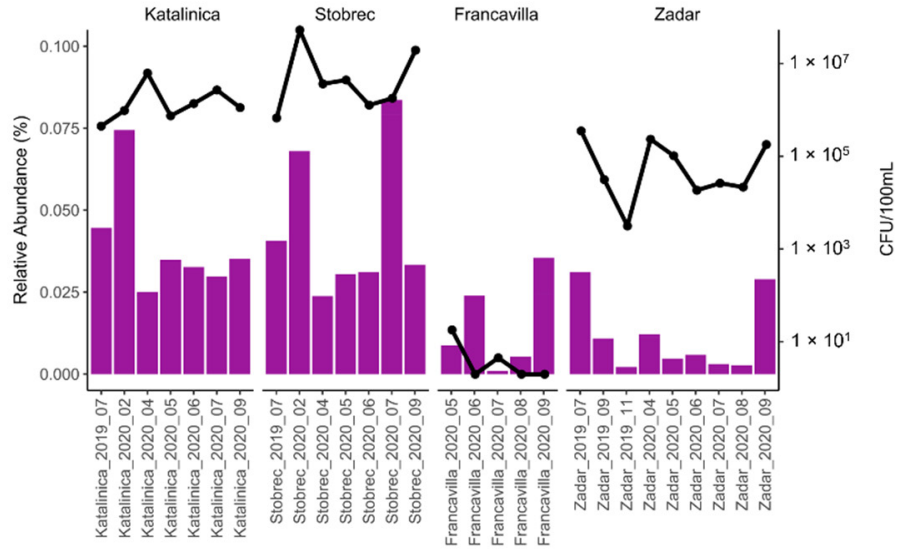

(b)

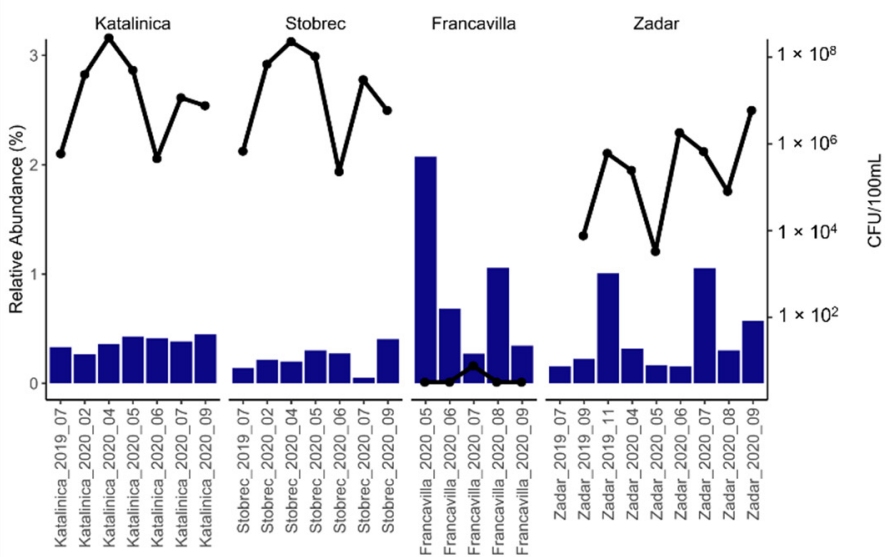

(c)

Figure 7. Comparison between 16S rRNA metagenetics data and plate count data for FIB and Pseudomonas aeruginosa. (a) Escherichia coli. (b) Enterococci. (c) P. aeruginosa. Plate count data are shown as solid black lines and 16S rDNA relative abundances as colored bars. 
On the contrary, the 16S rRNA relative abundances and the plate count data of Katalinića, Stobreč, and Zadar treated sewages followed comparable patterns. Although metagenomics investigations do not provide evidence of activity or for bacteria to be alive, regrowth experiments demonstrated that disinfection processes could inactivate or damage bacteria while not necessarily killing them [63,71,72]. Moreover, cultivation methods can overestimate the efficiency of disinfection treatment as damaged cells can lose culturability for short or long periods $[7,73]$. The discrepancy between NGS data and plated count in Francavilla treated sewage was particularly evident for the Pseudomonas genus, an emerging pathogen of environmental relevance that can survive and adapt to a diversity of environments [34,74]. Alternative fecal indicator taxa (i.e., five bacterial families constituting up to $85 \%$ of total sequences in human and animal feces, and three genera very abundant in urban WWTPs while not prevalent in human feces) covered high proportions of the bacterial diversity in all treated sewages here investigated, despite differences between types of treatments.

Seawater samples collected next to WWTP discharging points revealed a marked fecal signature, despite evident mitigation due to the dilution of the treated sewage plumes. Alternative fecal indicator taxa provided a better understanding of the actual fecal bacterial load in marine samples compared to traditional bacterial indicators that could not even be detected into the microbiome. In addition, NGS showed the presence of potentially pathogenic bacteria, especially Acinetobacter, Coxiella, Prevotella, Streptococcus, Pseudomonas, Vibrio, Empedobacter, Paracoccus, and Leptotrichia. The large majority of PPB phylotypes were shared between treated sewage and seawater samples, except for Vibrio and Coxiella, suggesting that WWTPs may represent the primary source for PPB in marine areas investigated in this study. Indeed, the presence of Vibrio, Pseudomonas, and Coxiella phylotypes in marine waters is not uncommon due to the ubiquitous nature of representatives of these genera [75-77]. However, deeper investigations and the use of long-read sequencing approaches may reveal differences that could not be appreciated with the methodologies chosen for the purposes of this study. Seawater samples collected next to Katalinića WWTP discharging points showed the highest content in traditional and alternative fecal indicator bacteria, while statistically significant differences with all the other sites, suggesting that the local hydrographic characteristics could contribute to a scarce dilution of the sewage plume.

WWTPs in this study represented continuous sources of erm B, qnrS, sul2, and tetA genes for coastal marine water. The three Croatian WWTPs (both with and without secondary biological treatment) were also important sources of the bla $a_{\mathrm{TEM}}$ gene, which codes for one of the most common beta-lactamase enzymes in Gram-negative bacteria, thus conferring resistance to ampicillin [78]. Contrary to what was expected, the bla ${ }_{\mathrm{CTX}-\mathrm{M}}$ gene was found in low concentrations in the Katalinića WWTP effluent and in $<$ LOQ or null concentrations in the other WWTPs. It has been hypothesized that urban WWTPs are the principal source of $b l a_{\mathrm{CTX}-\mathrm{M}}$ for aquatic environments $[23,51]$ because $b l a_{\mathrm{CTX}-\mathrm{M}}$ harboring strains isolated in rivers and wastewater were found to be related to nosocomial strains of the same geographical area $[79,80]$.

Although the two WWTPs with only primary treatments (i.e., Katalinića and Stobreč) were characterized by a more constant presence of ARGs over time, differences between genes were often not associated with the type of treatment (i.e., primary vs. secondary), except for sul2 (significantly higher in the presence of secondary treatment) and ermB (significantly lower in the presence of secondary treatment). Differences observed in this study were gene-specific and were likely related to the geographical origin of the corresponding wastewater streams. Francavilla WWTP was characterized by the absence or by low concentrations of ermB, bla $a_{\mathrm{TEM}}, b l a_{\mathrm{OXA}}$, and $b l a_{\mathrm{CTX}-\mathrm{M}}$. Although sewage in Francavilla WWTP undergoes final disinfection with peracetic acid, the disinfection by chemicals (e.g., chlorination or with peracetic acid) is known to be effective in minimizing the release of pathogens, but they would not affect the concentration of ARGs in treated sewage (when normalized to the $16 \mathrm{~S}$ copy number) [7]. On the contrary, disinfection may favor the co-selection of antibiotic-resistant bacteria, although results of previous 
investigations were sometimes contrasting $[7,63,71,81,82]$. In particular, it was observed that chlorination could promote HGT events $[83,84]$, which may favor AMR spreading and emerging of new AMR mechanisms. Due to its small size (i.e., 38,000 PE) Francavilla WWTP receives a lower inflow volume than the other WWTPs investigated in this study, which might relate to the observed lower concentrations for some ARGs.

One of the aims of this study was the assessment of a possible ARG chronic pollution into marine coastal waters affected by WWTP effluent discharge. To our knowledge, this is the first study investigating the presence over time of ARGs in the Adriatic Sea and one of the few ones in the Mediterranean Sea. Di Cesare and co-authors [85] investigated the presence of $e r m \mathrm{~B}, q n r \mathrm{~S}, t e t \mathrm{~A}$, and $b l_{\mathrm{TEM}}$ in marine sediments collected from the Pula Bay (Croatia, Adriatic Sea), one of the most significantly polluted sites along the Croatian coast, and found that only ermB and bla points and that they generally remained below the quantification limits. Šamanić and coauthors [86] cultured chlorine-resistant bacteria from surface water collected from Croatian public beaches and found isolates resistant to clinically significant $\beta$-lactamases, such as $b l a_{\mathrm{CTX}-\mathrm{M}-15}, b l a_{\mathrm{CTX}-\mathrm{M}-3}, b l a_{\mathrm{SHV}-12}$, and $b l a_{\mathrm{TEM}}$.

As observed for the treated sewage, erm $\mathrm{B}, q n r \mathrm{~S}$, sul2, and tet $\mathrm{A}$ were found at sea in higher concentrations and more constantly than the other ARGs, despite the evident mitigation due to dilution. Only Katalinića seawater samples were always positive to ermB, qnrS, sul2, tet $\mathrm{A}$, and $b l a_{\mathrm{TEM}}$, probably because of the hydrographic characteristics of the area. We have not found $b a_{\text {CTX-M }}$ in seawater samples, likely due to its low levels in the treated sewage. $m c r-1$ was positive in few samples collected next to the Zadar, Stobreč, and Francavilla WWTP discharging points. Interestingly, the few positive Zadar and Francavilla seawater samples had higher concentrations than their corresponding effluents. That could suggest that other environmental sources are relevant for $m c r-1$ (and, thus, other ARGs) in marine environments. The current $m c r-1$ distribution has been achieved through multiple translocations. A likely driver for the global spread is the trade (i.e., livestock animals and meat), but poorly treated sewage and aquaculture (including integrated aquaculture systems) have been suggested as probable responsible for the worldwide dissemination of the $m c r$ gene variants in aquatic environments and as major hotspots for genetic recombination and horizontal gene transfer of $\mathrm{mcr}$ and $\mathrm{mcr}$-like genes $[9,87,88]$. To our knowledge, this is the second finding of the plasmid-mediated colistin resistance gene $m c r-1$ in the Adriatic Sea and one of the first for the Mediterranean Sea. A very recent study [86] has detected the $m c r-1$ gene in one bacterial strain isolated from a surface water sample collected in a Croatian public beach.

\section{Conclusions}

In this study, we investigated WWTPs over time as continuous point sources of microbial pollution for coastal water of the central Adriatic Sea. In the absence of secondary treatments, marine coastal waters received high inputs of fecal indicator bacteria and potentially pathogenic bacteria (including the emerging opportunistic pathogen Pseudomonas aeruginosa). Moreover, WWTPs under study represented continuous sources of genetic elements conferring resistance to major classes of antibiotics, with potential consequences on the emerging and the establishment of AMR pathways in the environmental microbial communities. NGS-based approaches provided a broader detection of specific taxa than classic microbiological techniques, especially in the presence of a final disinfection step, which could lead to an underestimation of fecal pollution. In particular, the exploration in the microbiomes of alternative fecal indicator taxa and potentially pathogenic bacteria allowed a more thorough understanding of emerging and potential pathogens spread into the environment from either low efficiency or conventional WWTPs. Overall, our results highlight the need for an improvement of wastewater treatment technologies, especially for those plants which perform primary treatment only, and stress the importance of dedicated monitoring programs at the WWTP discharge points at sea. 
Supplementary Materials: The following are available online at https:/ / www.mdpi.com/article/10 .3390/w13233335/s1, Figure S1: Rarefaction curves, Figure S2: Top phyla bar plots, Figure S3: PCoA of bacterial communities, Figure S4: Bar plot of ARGs in seawater samples, Table S1: Sample list, Table S2: Primer sets, Table S3: qPCR assays details.

Author Contributions: Conceptualization, V.F., P.D.N. and M.C.; methodology, V.F. and A.D.C.; validation, V.F., A.D.C. and M.C.; formal analysis, V.F. and J.Š.; data curation, V.F., A.D.C. and M.C.; writing—original draft preparation, V.F.; writing—review and editing, V.F., A.D.C., J.Š., P.D.N. and M.C.; visualization, V.F.; supervision, M.C.; project administration, M.C.; funding acquisition, P.D.N. All authors have read and agreed to the published version of the manuscript.

Funding: This research was funded by the 2014-2020 Interreg V-A Italy-Croatia CBC Programme through the project AdSWiM (Managed use of treated urban wastewater for the quality of the Adriatic Sea), ID 10046144.

Institutional Review Board Statement: Not applicable.

Informed Consent Statement: Not applicable.

Data Availability Statement: The data are available from the corresponding author, upon request. Nucleotide sequences are available at the NCBI Sequence Read Archive (SRA) with bioproject numbers PRJNA771212 and PRJNA771227.

Acknowledgments: The authors would like to thank the personnel of the University of Split and of ARTA Abruzzo for sampling activities. Microbiological data from Francavilla and from the Split depuration plants were provided by ARTA Abruzzo and Teaching IPH Split, respectively. The help of R. Andričević, A. Annibaldi, and S. Susmel throughout the implementation of the project is kindly acknowledged. The valuable comments of three anonymous reviewers on earlier versions of the manuscript helped to improve the article.

Conflicts of Interest: The authors declare no conflict of interest.

\section{References}

1. Medlicott, K.; Wester, A.; Gordon, B.; Montgomery, M.; Tayler, E.; Sutherland, D.; Schmoll, O.; De-Souza, M.; Koo-Oshima, S.; Da-Balogh, K.; et al. Technical Brief on Water, Sanitation, Hygiene and Wastewater Management to Prevent Infections and Reduce the Spread of Antimicrobial Resistance. WHO/FAO/OIE Recommendation Report. 2020. Available online: https: / / www.who.int/publications/i/item/9789240006416 (accessed on 29 July 2021).

2. Bruschi, A.; Lisi, I.; De Angelis, R.; Querin, S.; Cossarini, G.; Di Biagio, V.; Salon, S.; Solidoro, C.; Fassina, D.; Ancona, S.; et al. Indexes for the Assessment of Bacterial Pollution in Bathing Waters from Point Sources: The Northern Adriatic Sea CADEAU Service. J. Env. Manag. 2021, 293, 112878. [CrossRef]

3. Nogales, B.; Lanfranconi, M.P.; Piña-Villalonga, J.M.; Bosch, R. Anthropogenic Perturbations in Marine Microbial Communities. FEMS Microbiol. Rev. 2011, 35, 275-298. [CrossRef]

4. European Environment Agency. Towards a Cleaner Mediterranean: A Decade of Progress. Joint Map Report. In EEA Reports; Publications Office of the European Union: Copenhagen, Denmark, 2020.

5. Court of Justice of the European Union. Sentenza Della Corte. Inadempimento Di Uno Stato-Raccolta E Trattamento Delle Acque Reflue Urbane-Direttiva 91/271/CEE—Articoli 3, 4 e 10. Judgment of the Court N. ECLI:EU:C:2018:358, 31 May 2018. Available on line: https:/ / eur-lex.europa.eu/legal-content/IT/TXT/?uri=CELEX\%3A62017CJ0251 (accessed on 26 September 2021).

6. Paliaga, P.; Korlević, M.; Ivančić, I.; Najdek, M. Limited Influence of Primary Treated Sewage Waters on Bacterial Abundance, Production and Community Composition in Coastal Seawaters. Mar. Environ. Res. 2017, 131, 215-226. [CrossRef]

7. Di Cesare, A.; Corno, G.; Manaia, C.M.; Rizzo, L. Impact of Disinfection Processes on Bacterial Community in Urban Wastewater: Should We Rethink Microbial Assessment Methods? J. Environ. Chem. Eng. 2020, 8, 104393. [CrossRef]

8. Pazda, M.; Kumirska, J.; Stepnowski, P.; Mulkiewicz, E. Antibiotic Resistance Genes Identified in Wastewater Treatment Plant Systems-A Review. Sci. Total Environ. 2019, 697, 134023. [CrossRef] [PubMed]

9. Wang, J.; Chu, L.; Wojnárovits, L.; Takács, E. Occurrence and Fate of Antibiotics, Antibiotic Resistant Genes (ARGs) and Antibiotic Resistant Bacteria (ARB) in Municipal Wastewater Treatment Plant: An Overview. Sci. Total Environ. 2020, 744, 140997. [CrossRef] [PubMed]

10. Hendriksen, R.S.; Munk, P.; Njage, P.; van Bunnik, B.; McNally, L.; Lukjancenko, O.; Röderet, T.; Nieuwenhuijse, D.; Pedersen, S.K.; Kjeldgaard, J.; et al. Global Monitoring of Antimicrobial Resistance Based on Metagenomics Analyses of Urban Sewage. Nat. Commun. 2019, 10, 1124. [CrossRef]

11. Finley, R.L.; Collignon, P.; Larsson, D.G.J.; Mcewen, S.A.; Li, X.Z.; Gaze, W.H.; Reid-Smithet, R.; Timinounial, M.; Graham, D.W.; Topp, E. The Scourge of Antibiotic Resistance: The Important Role of the Environment. Clin. Infect. Dis. 2013, 57, 704-710. [CrossRef] [PubMed] 
12. Newton, R.J.; McClary, J.S. The Flux and Impact of Wastewater Infrastructure Microorganisms on Human and Ecosystem Health. Curr. Opin. Biotechnol. 2019, 57, 145-150. [CrossRef]

13. Corno, G.; Yang, Y.; Eckert, E.M.; Fontaneto, D.; Fiorentino, A.; Galafassi, S.; Zhang, T.; Di Cesare, A. Effluents of Wastewater Treatment Plants Promote the Rapid Stabilization of the Antibiotic Resistome in Receiving Freshwater Bodies. Water Res. 2019, 158, 72-81. [CrossRef]

14. Forsberg, K.J.; Reyes, A.; Wang, B.; Selleck, E.M.; Sommer, M.O.A.; Dantas, G. The Shared Antibiotic Resistome of Soil Bacteria and Human Pathogens. Science 2012, 337, 1107-1111. [CrossRef] [PubMed]

15. Lupo, A.; Coyne, S.; Berendonk, T.U. Origin and Evolution of Antibiotic Resistance: The Common Mechanisms of Emergence and Spread in Water Bodies. Front. Microbiol. 2012, 3, 18. [CrossRef] [PubMed]

16. Hernandez, R.J.; Hesse, E.; Dowling, A.J.; Coyle, N.M.; Feil, E.J.; Gaze, W.H.; Vos, M. Using the Wax Moth Larva Galleria Mellonella Infection Model to Detect Emerging Bacterial Pathogens. PeerJ 2019, 6, e6150. [CrossRef] [PubMed]

17. Mughini-Gras, L.; Dorado-García, A.; van Duijkeren, E.; van den Bunt, G.; Dierikx, C.M.; Bonten, M.J.; Bootsma, M.C.; Schmitt, H.; Hald, T.; Evers, E.G.; et al. Attributable sources of community-acquired carriage of Escherichia coli containing $\beta$-lactam antibiotic resistance genes: A population-based modelling study. Lancet Planet. Health 2019, 3, e357-e369. [CrossRef]

18. Cabral-Oliveira, J.; Pratas, J.; Mendes, S.; Pardal, M.A. Trace Elements in Edible Rocky Shore Species: Effect of Sewage Discharges and Human Health Risk Implications. Hum. Ecol. Risk Assess. Int. J. 2015, 21, 135-145. [CrossRef]

19. Leonard, A.F.C.; Singer, A.; Ukoumunne, O.C.; Gaze, W.H.; Garside, R. Is It Safe to Go back into the Water? A Systematic Review and Meta-Analysis of the Risk of Acquiring Infections from Recreational Exposure to Seawater. Int. J. Epidemiol. 2018, 47, 572-586. [CrossRef]

20. Leonard, A.F.C.; Garside, R.; Ukoumunne, O.C.; Gaze, W.H. A Cross-Sectional Study on the Prevalence of Illness in Coastal Bathers Compared to Non-Bathers in England and Wales: Findings from the Beach User Health Survey. Water Res. 2020, 176, 115700. [CrossRef]

21. Leonard, A.F.C.; Zhang, L.; Balfour, A.J.; Garside, R.; Hawkey, P.M.; Murray, A.K.; Ukoumunne, O.C.; Gaze, W.H. Exposure to and Colonisation by Antibi-Otic-Resistant E. coli in UK Coastal Water Users: Environmental Surveillance, Exposure Assessment, and Epidemiological Study (Beach Bum Survey). Environ. Int. 2018, 114, 326-333. [CrossRef]

22. Borja, A.; White, M.P.; Berdalet, E.; Bock, N.; Eatock, C.; Kristensen, P.; Leonard, A.; Lloret, J.; Pahl, S.; Parga, M.; et al. Moving toward an Agenda on Ocean Health and Human Health in Europe. Front. Mar. Sci. 2020, 7, 37. [CrossRef]

23. Eckert, E.M.; Di Cesare, A.; Malki, L.S.; Villiger, J.; Pernthaler, J.; Callieri, C.; Bertoni, R.; Corno, G. Seasonality of the Antibiotic Resistance Gene Bla CTX-M in Temperate Lake Maggiore. Hydrobiologia 2019, 843, 143-153. [CrossRef]

24. WHO. Guidelines for Safe Recreational Water Environments: Coastal and Fresh Waters; World Health Organization: Geneva, Switzerland, 2003; Volume 1.

25. European Parliament. Directive 2006/7/EC of the European Parliament and of the Council of 15 February 2006 Concerning the Management of Bathing Water Quality and Repealing Directive 76/160/EEC. 4.3.2006(L64/37). Available online: https:/ / op.europa.eu/en/publication-detail/-/publication/c137dbd0-21c5-492f-81ad-736a1295fc68/language-en (accessed on 26 September 2021).

26. Mohammed, R.L.; Echeverry, A.; Stinson, C.M.; Green, M.; Bonilla, T.D.; Hartz, A.; McCorquodale, D.S.; Rogerson, A.; Esiobu, N. Survival Trends of Staphylococcus aureus, Pseudomonas Aeruginosa, and Clostridium Perfringens in a Sandy South Florida Beach Mar. Pollut. Bull. 2012, 64, 1201-1209. [CrossRef] [PubMed]

27. Marino, F.J.; Morinigo, M.A.; Martinez-Manzanares, E.; Borrego, J.J. Microbiological-Epidemiological Study of Selected Marine Beaches in Malaga (Spain). Water Sci. Technol. 1995, 31, 5-9. [CrossRef]

28. Pougnet, R.; Pougnet, L.; Allio, I.; Lucas, D.; Dewitte, J.D.; Loddé, B. Maritime Environment Health Risks Related to Pathogenic Microorganisms in Seawater. Int. Marit. Health 2018, 69, 35-45. [CrossRef]

29. Di Cesare, A.; Pasquaroli, S.; Vignaroli, C.; Paroncini, P.; Luna, G.M.; Manso, E.; Biavasco, F. The Marine Environment as a Reservoir of Enterococci Carrying Resistance and Virulence Genes Strongly Associated with Clinical Strains. Environ. Microbiol. Rep. 2014, 6, 184-190. [CrossRef]

30. Perini, L.; Quero, G.M.; Serrano García, E.; Luna, G.M. Distribution of Escherichia Coli in a Coastal Lagoon (Venice, Italy): Temporal Patterns, Genetic Diversity and the Role of Tidal Forcing. Water Res. 2015, 87, 155-165. [CrossRef]

31. Luna, G.M.; Quero, G.M.; Perini, L. Next Generation Sequencing Reveals Distinct Fecal Pollution Signatures in Aquatic Sediments across Gradients of Anthropogenic Influence. Adv. Oceanogr. Limnol. 2016, 7, 115-124. [CrossRef]

32. Susmel, S.; Figueredo, F.; Aissa, S.B.; Scognamiglio, V.; Antonacci, A.; Girolametti, F.; Annibaldi, A.; Fonti, V.; Celussi, M.; Manna, V.; et al. A new cross-cutting vision for the quality of the Adriatic Sea under the development of the Interreg project AdSWiM. Transition from WasteWater Treatments (WWT) plant to Water Resource Recovery Facilities (WRRFs) in dialogue with Universities and Research. Water. in prep, in this issue.

33. Kvesić, M.; Vojković, M.; Kekez, T.; Maravić, A.; Andričević, R. Spatial and Temporal Vertical Distribution of Chlorophyll in Relation to Submarine Wastewater Effluent Discharges. Water 2021, 13, 2016. [CrossRef]

34. De Bentzmann, S.; Plésiat, P. The Pseudomonas Aeruginosa Opportunistic Pathogen and Human Infections. Environ. Microbiol. 2011, 13, 1655-1665. [CrossRef]

35. López-Causapé, C.; Cabot, G.; del Barrio-Tofiño, E.; Oliver, A. The Versatile Mutational Resistome of Pseudomonas Aeruginosa. Front. Microbiol. 2018, 9, 1-9. [CrossRef] 
36. Potron, A.; Poirel, L.; Nordmann, P. Emerging Broad-Spectrum Resistance in Pseudomonas Aeruginosa and Acinetobacter Baumannii: Mechanisms and Epidemiology. Int. J. Antimicrob. Agents 2015, 45, 568-585. [CrossRef] [PubMed]

37. Celussi, M.; Quero, G.M.; Zoccarato, L.; Franzo, A.; Corinaldesi, C.; Rastelli, E.; Lo Martire, M.; Galand, P.E.; Ghiglione, J.F.; Chiggiato, J.; et al. Planktonic Prokaryote and Protist Communities in a Submarine Canyon System in the Ligurian Sea (NW Mediterranean). Prog. Oceanogr. 2018, 168, 210-221. [CrossRef]

38. 16S Metagenomic Sequencing Library Preparation. 2013. Available online: https://emea.illumina.com/content/dam/illuminasupport/documents/documentation/chemistry_documentation/16s/16s-metagenomic-library-prep-guide-15044223-b.pdf (accessed on 29 July 2021).

39. Morgan, M.; Anders, S.; Lawrence, M.; Aboyoun, P.; Pages, H.; Gentleman, R. ShortRead: A Bioconductor Package for Input, Quality Assessment and Exploration of High-Throughput Sequence Data. Bioinformatics 2009, 25, 2607-2608. [CrossRef] [PubMed]

40. Callahan, B.J.; McMurdie, P.J.; Rosen, M.J.; Han, A.W.; Johnson, A.J.A.; Holmes, S.P. DADA2: High-Resolution Sample Inference from Illumina Amplicon Data. Nat. Methods 2016, 13, 581-583. [CrossRef]

41. R Core Team. R: A Language and Environment for Statistical Computing; R Foundation for Statistical Computing: Vienna, Austria, 2021.

42. Wang, Q.; Garrity, G.M.; Tiedje, J.M.; Cole, J.R. Naïve Bayesian Classifier for Rapid Assignment of rRNA Sequences into the New Bacterial Taxonomy. Appl Environ. Microbiol. 2007, 73, 5261-5267. [CrossRef]

43. Quast, C.; Pruesse, E.; Yilmaz, P.; Gerken, J.; Schweer, T.; Yarza, P.; Peplies, J.; Glöckner, F.O. The SILVA Ribosomal RNA Gene Database Project: Im-Proved Data Processing and Web-Based Tools. Nucleic Acids Res. 2013, 41, D590-D596. [CrossRef]

44. Yilmaz, P.; Parfrey, L.W.; Yarza, P.; Gerken, J.; Pruesse, E.; Quast, C.; Schweer, T.; Peplies, J.; Ludwig, W.; Glöckner, F.O. The SILVA and "All-Species Living Tree Project (LTP)" Taxonomic Frameworks. Nucleic Acids Res. 2014, 42, D643-D648. [CrossRef]

45. Wickham, H. ggplot2: Elegant Graphics for Data Analysis. J. Stat. Softw. 2016, 77, 1-3.

46. McMurdie, P.J.; Holmes, S. Phyloseq: An R Package for Reproducible Interactive Analysis and Graphics of Microbiome Census Data. PLoS ONE 2013, 8, e61217. [CrossRef]

47. Kandlikar, G.S.; Gold, Z.J.; Cowen, M.C.; Meyer, R.S.; Freise, A.; Kraft, N.J.B.; Moberg-Parker, J.; Sprague, J.; Kushner, D.J.; Curd, E.E. Ranacapa: An R Package and Shiny Web App to Explore Environmental DNA Data with Exploratory Statistics and Interactive Visualizations. F1000Research 2018, 7, 1734. [CrossRef]

48. Bolyen, E.; Rideout, J.R.; Dillon, M.R.; Bokulich, N.A.; Abnet, C.C.; Al-Ghalith, G.A.; Alexander, H.; Alm, E.J.; Arumugam, M.; Asnicar, F. Reproducible, Interactive, Scalable and Extensible Microbiome Data Science Using QIIME 2. Nat. Biotechnol. 2019, 37, 852-857. [CrossRef]

49. Katoh, K.; Standley, D.M. MAFFT Multiple Sequence Alignment Software Version 7: Improvements in Performance and Usability. Mol. Biol. Evol. 2013, 30, 772-780. [CrossRef] [PubMed]

50. Price, M.N.; Dehal, P.S.; Arkin, A.P. FastTree 2-Approximately Maximum-Likelihood Trees for Large Alignments. PLoS ONE 2010, 5, e9490. [CrossRef] [PubMed]

51. Di Cesare, A.; Eckert, E.M.; Teruggi, A.; Fontaneto, D.; Bertoni, R.; Callieri, C.; Corno, G. Constitutive Presence of Antibiotic Resistance Genes within the Bacterial Community of a Large Subalpine Lake. Mol. Ecol. 2015, 24, 3888-3900. [CrossRef]

52. Di Cesare, A.; Luna, G.M.; Vignaroli, C.; Pasquaroli, S.; Tota, S.; Paroncini, P.; Biavasco, F. Aquaculture Can Promote the Presence and Spread of Antibiotic-Resistant Enterococci in Marine Sediments. PLoS ONE 2013, 8, e62838.

53. McArthur, A.G.; Waglechner, N.; Nizam, F.; Yan, A.; Azad, M.A.; Baylay, A.J.; Bhullar, K.; Canova, M.J.; Pascale, G.D.; Ejim, L.; et al. The Comprehensive Antibiotic Resistance Database. Antimicrob. Agents Chemother. 2013, 57, 3348-3357. [CrossRef]

54. Hou, Y.; Zhang, H.; Miranda, L.; Lin, S. Serious Overestimation in Quantitative PCR by Circular (Supercoiled) Plasmid Standard: Microalgal pcnaas the Model Gene. PLoS ONE 2010, 5, e9545. [CrossRef]

55. Ng, L.K.; Martin, I.; Alfa, M.; Mulvey, M. Multiplex PCR for the Detection of Tetracycline Resistant Genes. Mol. Cell Probes. 2001, 15, 209-215. [CrossRef]

56. Pei, R.; Kim, S.C.; Carlson, K.H.; Pruden, A. Effect of River Landscape on the Sediment Concentrations of Antibiotics and Corre-sponding Antibiotic Resistance Genes (ARG). Water Res. 2006, 40, 2427-2435. [CrossRef]

57. Marti, E.; Balcázar, J.L. Real-Time PCR Assays for Quantification of qnr Genes in Environmental Water Samples and Chicken Feces. Appl. Environ. Microbiol. 2013, 79, 1743-1745. [CrossRef]

58. Marti, E.; Jofre, J.; Balcazar, J.L. Prevalence of Antibiotic Resistance Genes and Bacterial Community Composition in a River Influenced by a Wastewater Treatment Plant. PLoS ONE 2013, 8, e78906.

59. Bontron, S.; Poirel, L.; Nordmann, P. Real-Time PCR for Detection of Plasmid-Mediated Polymyxin Resistance (mcr-1) from Cultured Bacteria and Stools. J. Antimicrob. Chemother. 2016, 71, 2318-2320. [CrossRef]

60. Bibbal, D.; Dupouy, V.; Ferré, J.P.; Toutain, P.L.; Fayet, O.; Prère, M.F.; Bousquet-Mélou, A. Impact of Three Ampicillin Dosage Regimens on Selection of Ampicillin Resistance in Enterobacteriaceae and Excretion of blaTEM Genes in Swine Feces. Appl. Environ. Microbiol. 2007, 73, 4785-4790. [CrossRef] [PubMed]

61. Subirats, J.; Royo, E.; Balcázar, J.L.; Borrego, C.M. Real-Time PCR Assays for the Detection and Quantification of Carbapenemase Genes (bla KPC, bla NDM, and bla OXA-48) in Environmental Samples. Environ. Sci. Pollut. Res. 2017, 24, 6710-6714. [CrossRef]

62. Bustin, S.A.; Benes, V.; Garson, J.A.; Hellemans, J.; Huggett, J.; Kubista, M.; Mueller, R.; Nolan, T.; Pfaffl, M.W.; Shipley, G.L.; et al. The MIQE Guidelines: Minimum Information for Publication of Quantitative Real-Time PCR Experiments. Clin. Chem. 2009, 55, 611-622. [CrossRef] 
63. Di Cesare, A.; Fontaneto, D.; Doppelbauer, J.; Corno, G. Fitness and Recovery of Bacterial Communities and Antibiotic Resistance Genes in Urban Wastewaters Exposed to Classical Disinfection Treatments. Environ. Sci. Technol. 2016, 50, 10153-10161. [CrossRef] [PubMed]

64. Zuur, A.F.; Ieno, E.N.; Elphick, C.S. A Protocol for Data Exploration to Avoid Common Statistical Problems. Methods Ecol. Evol. 2010, 1, 3-14. [CrossRef]

65. McMurdie, P.J.; Holmes, S.P. Waste Not, Want Not: Why Rarefying Microbiome Data Is Inadmissible. PLoS Comput. Biol. 2014, 10, e1003531. [CrossRef]

66. Steinberger, A. Seq-Scripts Release v. 1.0. 2016. Available online: https:/ / zenodo.org/record/1458243\#.YZ4Po9BByUk (accessed on 29 July 2021).

67. Newton, R.J.; Bootsma, M.J.; Morrison, H.G.; Sogin, M.L.; McLellan, S.L. A Microbial Signature Approach to Identify Fecal Pollution in the Waters Off an Urbanized Coast of Lake Michigan. Microb. Ecol. 2013, 65, 1011-1023. [CrossRef]

68. WHO. Microbial Fact Sheets. In World Health Organization Guidelines for Drinking-Water Quality (WHO GDWQ); WHO: Geneva, Switzerland, 2011.

69. Janda, J.M. Shewanella: A Marine Pathogen as an Emerging Cause of Human Disease. Clin. Microbiol. Newsl. 2014, 36, 25-29. [CrossRef]

70. Love, M.I.; Huber, W.; Anders, S. Moderated Estimation of Fold Change and Dispersion for RNA-seq Data with DESeq2. Genome Biol. 2014, 15, 550. [CrossRef]

71. Bürgmann, H.; Frigon, D.; Gaze, W.H.; Manaia, C.M.; Pruden, A.; Singer, A.C.; Smets, B.F.; Zhang, T. Water and Sanitation: An Essential Battlefront in the War on Antimicrobial Resistance. FEMS Microbiol. Ecol. 2018, 94, fiy101. [CrossRef]

72. Fiorentino, A.; Ferro, G.; Alferez, M.C.; Polo-López, M.I.; Fernández-Ibañez, P.; Rizzo, L. Inactivation and Regrowth of Multidrug Resistant Bacteria in Urban Wastewater after Disinfection by Solar-Driven and Chlorination Processes. J. Photochem. Photobiol. B Biol. 2015, 148, 43-50. [CrossRef]

73. Lazarova, V.; Janex, M.L.; Fiksdal, L.; Oberg, C.; Barcina, I.; Pommepuy, M. Advanced Wastewater Disinfection Technologies: Short and Long Term Efficiency. Water Sci. Technol. 1998, 38, 109-117. [CrossRef]

74. Wade, T.J.; Sams, E.A.; Beach, M.J.; Collier, S.A.; Dufour, A.P. The Incidence and Health Burden of Earaches Attributable to Recrea-Tional Swimming in Natural Waters: A Prospective Cohort Study. Environ. Health 2013, 12, 67. [CrossRef]

75. Bonadonna, L.; Briancesco, R.; Coccia, A.M.; Semproni, M.; Stewardson, D. Occurrence of Potential Bacterial Pathogens in Coastal Areas of the Adriatic Sea. Environ Monit. Assess. 2002, 77, 31-49. [CrossRef] [PubMed]

76. Fabbro, C.; Celussi, M.; Russell, H.; Del Negro, P. Phenotypic and Genetic Diversity of Coexisting Listonella Anguillarum, Vibrio Harveyi and Vibrio Chagassi Recovered from Skin Haemorrhages of Diseased Sand Smelt, Atherina Boyeri, in the Gulf of Trieste (NE Adriatic Sea). Lett. Appl. Microbiol. 2012, 54, 153-159. [CrossRef] [PubMed]

77. Bacosa, H.P.; Liu, Z.; Erdner, D.L. Natural Sunlight Shapes Crude Oil-Degrading Bacterial Communities in Northern Gulf of Mexico Surface Waters. Front. Microbiol. 2015, 6, 1325. [CrossRef]

78. Weitz, J.S.; Stock, C.A.; Wilhelm, S.W.; Bourouiba, L.; Coleman, M.L.; Buchan, A.; Follows, M.J.; Fuhrman, J.A.; Jover, L.F.; Lennon, J.T.; et al. A Multitrophic Model to Quantify the Effects of Marine Viruses on Microbial Food Webs and Ecosystem Processes. ISME J. 2015, 9, 1352-1364. [CrossRef] [PubMed]

79. Varela, A.R.; Manageiro, V.; Ferreira, E.; Guimarães, M.A.; da Costa, P.M.; Caniça, M.; Manaia, C.M. Molecular Evidence of the Close Relat-Edness of Clinical, Gull and Wastewater Isolates of Quinolone-Resistant Escherichia Coli. J. Glob. Antimicrob. Resist. 2015, 3, 286-289. [CrossRef]

80. Abgottspon, H.; Nüesch-Inderbinen, M.T.; Zurfluh, K.; Althaus, D.; Hächler, H.; Stephan, R. Enterobacteriaceae with Extended-Spectrum-and pAmpC-Type $\beta$-Lactamase-Encoding Genes Isolated from Freshwater Fish from Two Lakes in Switzerland. Antimicrob. Agents Chemother. 2014, 58, 2482-2484. [CrossRef] [PubMed]

81. Chen, L.; Huang, L.; Méndez-García, C.; Kuang, J.; Hua, Z.; Liu, J.; Shu, W.S. Microbial Communities, Processes and Functions in Acid Mine Drainage Ecosystems. Curr. Opin. Biotechnol. 2016, 38, 150-158. [CrossRef] [PubMed]

82. Lin, W.; Zhang, M.; Zhang, S.; Yu, X. Can Chlorination Co-Select Antibiotic-Resistance Genes? Chemosphere 2016, 156, 412-419. [CrossRef] [PubMed]

83. Guo, M.T.; Yuan, Q.B.; Yang, J. Distinguishing Effects of Ultraviolet Exposure and Chlorination on the Horizontal Transfer of Antibiotic Resistance Genes in Municipal Wastewater. Environ. Sci. Technol. 2015, 49, 5771-5778. [CrossRef]

84. Zhang, Y.; Li, A.; Dai, T.; Li, F.; Xie, H.; Chen, L.; Wen, D. Cell-Free DNA: A Neglected SOURCE for Antibiotic Resistance Genes Spreading from WWTPs. Environ. Sci. Technol. 2018, 52, 248-257. [CrossRef]

85. Di Cesare, A.; Pjevac, P.; Eckert, E.; Curkov, N.; Miko Šparica, M.; Corno, G.; Orlić, S. The Role of Metal Contamination in Shaping Microbial Communities in Heavily Polluted Marine Sediments. Environ. Pollut. 2020, 265, 114823. [CrossRef]

86. Šamanić, I.; Kalinić, H.; Fredotović, Ž.; Dželalija, M.; Bungur, A.M.; Maravić, A. Bacteria Tolerant to Colistin in Coastal Marine Environment: Detection, Microbiome Diversity and Antibiotic Resistance genes' Repertoire. Chemosphere 2021, $281,130945$. [CrossRef] 
87. Lozano-Leon, A.; Garcia-Omil, C.; Dalama, J.; Rodriguez-Souto, R.; Martinez-Urtaza, J.; Gonzalez-Escalona, N. Detection of Col-istin Resistance mcr-1 Gene in Salmonella Enterica Serovar Rissen Isolated from Mussels, Spain, 2012 to 2016. Eurosurveillance 2019, 24, 1900200. [CrossRef]

88. Cabello, F.C.; Godfrey, H.P. Aquaculture, Exaptation, and the Origin of mcr-Positive Colistin Resistance. Antimicrob. Agents Chemother. 2018, 62, e01903-18. [CrossRef] 